\title{
Variability in Lignin Composition and Structure in Cell Walls of Different Parts of Macaúba (Acrocomia aculeata) Palm Fruit
}

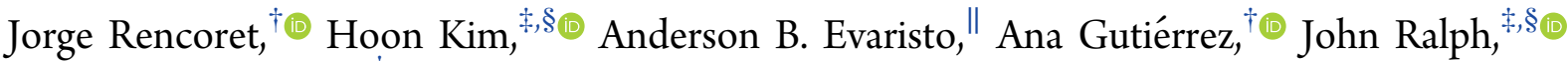 \\ and José C. del Río*i† \\ ${ }^{\dagger}$ Instituto de Recursos Naturales y Agrobiología de Sevilla (IRNAS), CSIC, Av. Reina Mercedes, 10, 41012 Seville, Spain \\ ${ }^{\ddagger}$ Department of Energy Great Lakes Bioenergy Research Center, Wisconsin Energy Institute, University of Wisconsin-Madison, \\ Madison, Wisconsin 53726, United States \\ ${ }^{\S}$ Department of Biochemistry, University of Wisconsin-Madison, Madison, Wisconsin 53706, United States \\ "Department of Agronomy, Universidade Estadual do Tocantins, Palmas, TO, Brazil
}

Supporting Information

ABSTRACT: The lignins from different anatomical parts of macaúba (Acrocomia aculeata) palm fruit, namely stalks, epicarp, and endocarp, were studied. The lignin from stalks was enriched in S-lignin units (S/G 1.2) and $\beta$-ether linkages (84\% of the total) and was partially acylated at the $\gamma-\mathrm{OH}$ of the lignin side-chains ( $26 \%$ lignin acylation), predominantly with $p$ hydroxybenzoates and acetates. The epicarp lignin was highly enriched in G-lignin units (S/G 0.2) and consequently depleted in $\beta$-ethers $(65 \%)$ and enriched in condensed structures such as phenylcoumarans (24\%) and dibenzodioxocins (3\%). The endocarp lignin was strikingly different from the rest and presented large amounts of piceatannol units incorporated into the polymer. This resulted in a lignin polymer depleted in $\beta$-ethers but enriched in condensed structures and linked piceatannol moieties. The incorporation of piceatannol into the lignin polymer seems to have a role in seed protection.

KEYWORDS: stalk, epicarp, endocarp, stilbenes, piceatannol, Py-GC/MS, 2D-NMR, DFRC

\section{INTRODUCTION}

Macaúba (Acrocomia aculeata (Jacq.) Lodd. ex Mart.) is a tropical palm tree from the Arecaceae family native to South America. This palm is considered a promising energy crop due to the high bioenergy production potential of its fruit and the possibility of integrated crop-livestock/forest-farming systems. The fruit has a high oil content, which has favorable characteristics for the production of biodiesel. ${ }^{1-3}$ In addition, from the residues generated in the processing of the fruits, it is possible to produce charcoal (from the shell) and densified briquettes (from the husk), both biofuels of high energy density. $^{1-3}$

The macaúba fruit is a drupe with a smooth epicarp (husk) and a fibrous mesocarp (pulp) that involves the nut, which comprises the endocarp (shell) and the kernel. The oil is concentrated in the pulp and the kernel, which are the parts industrially exploited, whereas the other parts of the fruit, epicarp, and endocarp are mostly discarded as residues generated during oil production. ${ }^{1-3}$ The epicarp and endocarp are the lignified layers of the fruit pericarp. The epicarp is formed by compact parenchyma cells whereas the endocarp is formed of sclerenchyma cells. ${ }^{4}$ A previous study has shown that palm fruit endocarps contain substantial amounts of hydroxystilbenes (particularly piceatannol, together with minor amounts of resveratrol and isorhapontigenin), integrally incorporated into the lignin polymer. ${ }^{5}$ Palm fruit endocarps can therefore be regarded as a source of valuable polyphenolics from what is now considered a waste material. However, it is not yet known whether these valuable hydroxystilbenes are restricted to the endocarp layer or whether they are also present in the lignins of other parts of the same plant. For this reason, the content and structural characteristics of the lignins from three distinct lignified anatomical parts of the macaúba palm, namely stalks, and the epicarp and endocarp from the fruit, have been investigated in detail.

Lignin is an abundant biopolymer in vascular plants where it plays crucial roles for plant growth and development, as well as for pathogen protection. Lignin derives primarily from three hydroxycinnamyl alcohols, $p$-coumaryl, coniferyl, and sinapyl alcohols; following lignification, these differentially methoxylated monolignols give rise to the p-hydroxyphenyl $(\mathbf{H})$, guaiacyl (G), and syringyl (S) units in the polymer. ${ }^{6}$ Abundant research has indicated that lignins are also produced from monomers other than the three traditional monolignols, including acylated monolignols (with acetates, $p$-hydroxybenzoates, $p$-coumarates, and ferulates), as well as other phenolics arising from truncated monolignol biosynthesis, such as coniferaldehyde, 5-hydroxyconiferyl alcohol, or caffeyl alcohol. ${ }^{6-14}$ Interestingly, phenolic compounds derived from outside the classical monolignol biosynthetic pathway have now also been discovered to participate in cross-coupling reactions with monolignols to become integrally incorporated into the lignin. This is the case for the flavone tricin, discovered in grasses and other monocots ${ }^{11,15-19}$ and the

Received: October 9, 2017

Revised: December 13, 2017

Accepted: December 15, 2017

Published: December 15, 2017 
aforementioned hydroxystilbenes (e.g., piceatannol) recently discovered in the lignins of several palm fruit endocarps. ${ }^{5}$

The content, composition, and structure of the lignin differ widely and depend on many factors, including the type of plants, tissues, cell-type, stages of growth, and also the environmental conditions. ${ }^{20-24}$ Lignin deposition and composition is cell-specific and therefore differs between xylem cells specialized for water and solutes transportation (tracheary elements), sclerenchyma cells that ensure the mechanical support of plants, and endodermal cells. ${ }^{25,26}$ Lignin deposition and assembly is regulated by the cell which determines the supply of the different monolignols to the lignifying zones of the various tissues. ${ }^{21,27-29}$ It is therefore expected that the lignins from the three macaúba parts selected for this study (stalk, epicarp, and endocarp) have different compositions.

In this study, the whole cell walls of the different macaúba parts were analyzed "in situ" by two-dimensional nuclear magnetic resonance (2D-NMR) spectroscopy and by analytical pyrolysis coupled to gas chromatography and mass spectrometry (Py-GC/MS). The use of these techniques avoids isolation procedures that may only partially extract the lignin, not necessarily representatively, or may result in undesirable modifications. However, in order to obtain superior spectra and aid in lignin structural assignment, so-called "milled wood" lignins (MWLs) were also isolated from the different macaúba parts and subsequently analyzed by 2D-NMR, Py-GC/MS, derivatization followed by reductive cleavage (DFRC), and gelpermeation chromatography (GPC).

\section{EXPERIMENTAL SECTION}

Samples. Bunches of matured fruits were collected from macaúba (Acrocomia aculeata) palm plantations in Mirabela, MG, Brazil. The epicarp and endocarp of the fruit were manually separated with a cutter and, together with the stalks, were dried in a forced-air oven at $40{ }^{\circ} \mathrm{C}$. The dried samples were milled using a knife mill and then successively Soxhlet extracted with acetone $(8 \mathrm{~h})$ and hot water $(3 \mathrm{~h})$ to remove extractives. Klason lignin content was estimated as the residue after sulfuric acid hydrolysis of the pre-extracted material (filtered through a porosity- 3 crucible), according to the TAPPI method T222 om- $88,{ }^{30}$ and then corrected for ash and protein content as previously described. ${ }^{16}$ In the hydrolysates, monomeric sugars from carbohydrates were analyzed by GC as alditol acetate derivatives according to TAPPI method T249 om- $85 .{ }^{30}$ Three replicates were used for each sample. The compositions of neutral monosaccharides (as percentages of total neutral carbohydrates) were as follows for the different macaúba parts. Stalks: arabinose (6.7\%), mannose (1.8\%), galactose $(2.5 \%)$, xylose $(27.4 \%)$, glucose $(61.6 \%)$. Epicarp: arabinose (3.1\%), mannose $(4.8 \%)$, galactose $(4.1 \%)$, xylose (18.8\%), glucose $(69.2 \%)$. Endocarp: arabinose $(0.9 \%)$, mannose $(0.8 \%)$, galactose $(0.8 \%)$, xylose $(45.3 \%)$, glucose $(52.2 \%)$.

Lignin Isolation. The "milled wood" lignin (MWL) preparations were obtained from extractive-free samples using ball-milling conditions more recently described. ${ }^{5}$ The ball-milled materials (40 g) were extracted with $800 \mathrm{~mL}$ of dioxane-water $(96: 4, \mathrm{v} / \mathrm{v})$ under continuous stirring in the dark for $24 \mathrm{~h}$. The solution was centrifuged and the supernatant, which contains the lignin, was then collected by decantation. The extraction process was repeated three times, using fresh dioxane-water solution each time and the supernatants were combined. Crude lignins were obtained after removal of the solvent on a rotary evaporator at $50{ }^{\circ} \mathrm{C}$ and the isolated lignins were subsequently purified as described elsewhere. ${ }^{31}$ Yields of around 20\% of the original Klason lignin content were obtained.

Analytical Pyrolysis. The pyrolysis of the different macaúba parts and their isolated lignins were performed at $500{ }^{\circ} \mathrm{C}(1 \mathrm{~min})$ in a 3030 microfurnace pyrolyzer (Frontier Laboratories Ltd., Fukushima, Japan) connected to a GC $7820 \mathrm{~A}$ (Agilent Technologies, Inc.,
Santa Clara, CA) and an Agilent 5975 mass-selective detector. The column used was a $30 \mathrm{~m} \times 0.25 \mathrm{~mm}$ i.d., $0.25 \mu \mathrm{m}$ film thickness, DB1701 (J\&W Scientific, Folsom, CA). The GC oven was heated from 50 to $100{ }^{\circ} \mathrm{C}$ at $20^{\circ} \mathrm{C} / \mathrm{min}$ and then ramped to $280{ }^{\circ} \mathrm{C}$ at $6{ }^{\circ} \mathrm{C} / \mathrm{min}$ and held for $5 \mathrm{~min}$. Helium $(1 \mathrm{~mL} / \mathrm{min})$ was used as the carrier gas. For the pyrolysis in the presence of tetramethylammonium hydroxide (Py/TMAH), the sample was mixed with a droplet of TMAH $(25 \%$, $\mathrm{w} / \mathrm{w}$, in methanol) prior to the pyrolysis. The released compounds were identified by comparison of their mass spectra with those present in the NIST and Wiley mass spectral libraries and by comparison with literature data. ${ }^{32}$

Derivatization Followed by Reductive Cleavage (DFRC). DFRC degradation was performed according to the classical procedure, ${ }^{33}$ and the details have been described elsewhere. ${ }^{31}$ Briefly, around $10 \mathrm{mg}$ of lignin were first treated with acetyl bromide/acetic acid solution $(8: 92, \mathrm{v} / \mathrm{v})$ under stirring $\left(2 \mathrm{~h}, 50{ }^{\circ} \mathrm{C}\right)$ and then treated with $50 \mathrm{mg}$ of powdered $\mathrm{Zn}$ (40 min, room temperature). The lignin degradation products were then acetylated with acetic anhydride/ pyridine prior to their analysis by GC/MS. To evaluate the occurrence of native acetate groups attached to the lignin, the original DFRC method was slightly modified by using propionylating reagents (so-called DFRC') instead of acetylating ones, as previously described. ${ }^{7,34}$ The DFRC and DFRC' lignin degradation products were analyzed by GC/MS on a Saturn 4000 (Varian, Walnut Creek, CA) equipment. The column used was a $15 \mathrm{~m} \times 0.25 \mathrm{~mm}$ i.d., $0.1 \mu \mathrm{m}$ film thickness, DB5-HT (J\&W Scientific, Folsom, CA). Helium (2 $\mathrm{mL} / \mathrm{min}$ ) was used as the carrier gas. The samples were injected directly onto the column using a septum-equipped programmable injector (Varian 8200 autosampler, Varian, Folsom, CA) that was heated from $120{ }^{\circ} \mathrm{C}(0.1 \mathrm{~min})$ to $340{ }^{\circ} \mathrm{C}$ at a rate of $200{ }^{\circ} \mathrm{C} / \mathrm{min}$ and held until the end of the analysis. The GC oven was heated from 120 ${ }^{\circ} \mathrm{C}(1 \mathrm{~min})$ to $340{ }^{\circ} \mathrm{C}(10 \mathrm{~min})$ at a rate of $10{ }^{\circ} \mathrm{C} / \mathrm{min}$. The GC/MS transfer line was set to $300{ }^{\circ} \mathrm{C}$.

Nuclear Magnetic Resonance (NMR) Spectroscopy. Multidimensional NMR spectra (HSQC, HMBC, HSQC-TOCSY) were recorded on an AVANCE III $500 \mathrm{MHz}$ instrument (Bruker, Karlsruhe, Germany) fitted with a cryogenically cooled $5 \mathrm{~mm}$ TCI gradient probe with inverse geometry, at the NMR facilities of the General Research Services of the University of Seville (SGI-CITIUS). Whole cell-walls were analyzed at "gel-state" according to previous methods; ${ }^{35,36}$ for this, $80 \mathrm{mg}$ of sample were swelled in $0.75 \mathrm{~mL}$ of DMSO- $d_{6}$. In the case of MWLs, $40 \mathrm{mg}$ of sample were dissolved in $0.75 \mathrm{~mL}$ of DMSO- $d_{6}$. The residual DMSO signal $\left(\delta_{\mathrm{C}} / \delta_{\mathrm{H}} 39.5 / 2.49\right)$ was used as the internal reference. The HSQC, HMBC, and HSQCTOCSY experiments used the Bruker standard pulse programs "hsqcetgpsisp2.2", "hmbcgplpndqf", and "hsqcdietgpsisp.2", respectively. The detailed NMR experimental conditions are described elsewhere. ${ }^{11}$ Lignin and carbohydrate signals were assigned according to the literature. ${ }^{5,11,15,31,35-38}$ Quantitation of lignin units and linkages were performed as described elsewhere. ${ }^{5,15}$ Briefly, the signals used to quantitate the relative abundances of the aromatic units were $\mathbf{H}_{2,6}, \mathbf{G}_{2}$, $\mathbf{S}_{2,6}, \boldsymbol{p} \mathbf{C A}_{2,6}, \mathbf{F A}_{2}, \boldsymbol{p} \mathbf{B A}_{2,6}$, and $\mathbf{P}_{\mathbf{c} 2}\left(\mathbf{P}_{\mathbf{b} 2}\right.$ was not resolved and its estimated integral was obtained via comparison of integrals for $\mathbf{P}_{\mathbf{b} 6}$ and $\mathbf{P}_{c 6}$ ); as signals $\mathbf{H}_{2,6}, \mathbf{S}_{2,6}, \boldsymbol{p} \mathbf{C A}_{2,6}$, and $\boldsymbol{p} \mathbf{B A}_{2,6}$ involve two protoncarbon pairs, their volume integrals were halved. The various interunit linkages were quantitated via the volume integrals of the $\mathbf{A}_{\alpha} / \mathbf{A}^{\prime}{ }_{\alpha}, \mathbf{B}_{\alpha} /$ $\mathbf{B}_{\alpha}^{\prime}, \mathbf{C}_{\alpha}, \mathbf{C}^{\prime}{ }_{\alpha}, \mathbf{D}_{\beta}, \mathbf{F}_{\alpha}, \mathbf{P}_{\mathbf{b} 7}, \mathbf{P}_{\mathbf{c} 7}$, and $\mathbf{V}_{\alpha}$ correlation signals. The relative abundance of cinnamyl alcohol end-groups (I) were estimated by integration of the signals $\mathbf{I}_{\gamma}$ and $\mathbf{I}^{\prime}{ }^{\prime}$, whereas the abundance of cinnamaldehyde end-groups $(\mathrm{J})$ was determined by integration of the signal $\mathbf{J}_{7}$ and comparing with $\mathbf{I}_{\beta}$.

Gel-Permeation Chromatography (GPC). Prior the GPC analyses, the MWLs were acetylated with acetic anhydride/pyridine $(1: 1, \mathrm{v} / \mathrm{v})$ and dissolved in tetrahydrofuran (THF). GPC was carried out on a Prominence-i LC-2030 3D GPC system (Shimadzu, Kyoto, Japan). The column used was a $300 \mathrm{~mm} \times 7.5 \mathrm{~mm}$ i.d., $5 \mu \mathrm{m}$, PLgel MIXED-D (Agilent Technologies, Stockport, United Kingdom). The eluent was THF at a flow rate of $0.5 \mathrm{~mL} / \mathrm{min}$ at a temperature of 40 ${ }^{\circ} \mathrm{C}$. The chromatograms were monitored at $280 \mathrm{~nm}$ using a photodiode array (PDA) detector. The data acquisition and 
A Stalk $\mathrm{CW}$

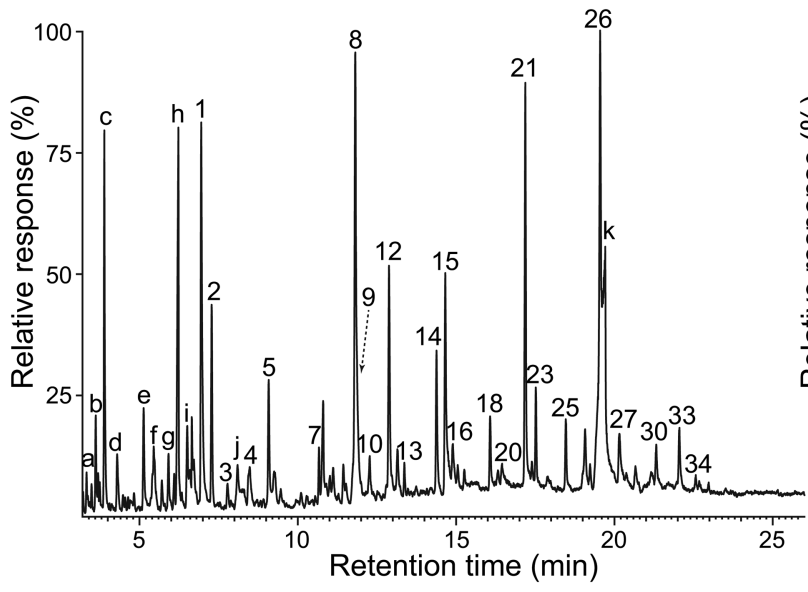

D Stalk MWL

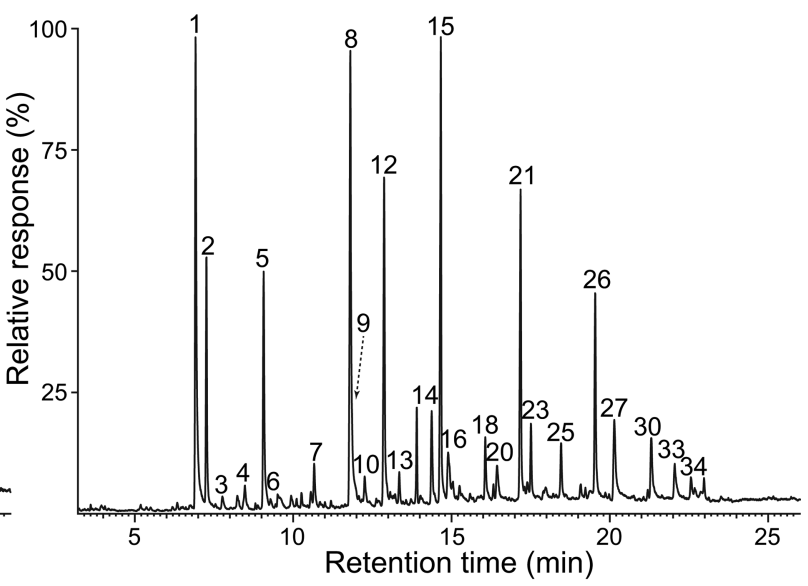

E Epicarp MWL
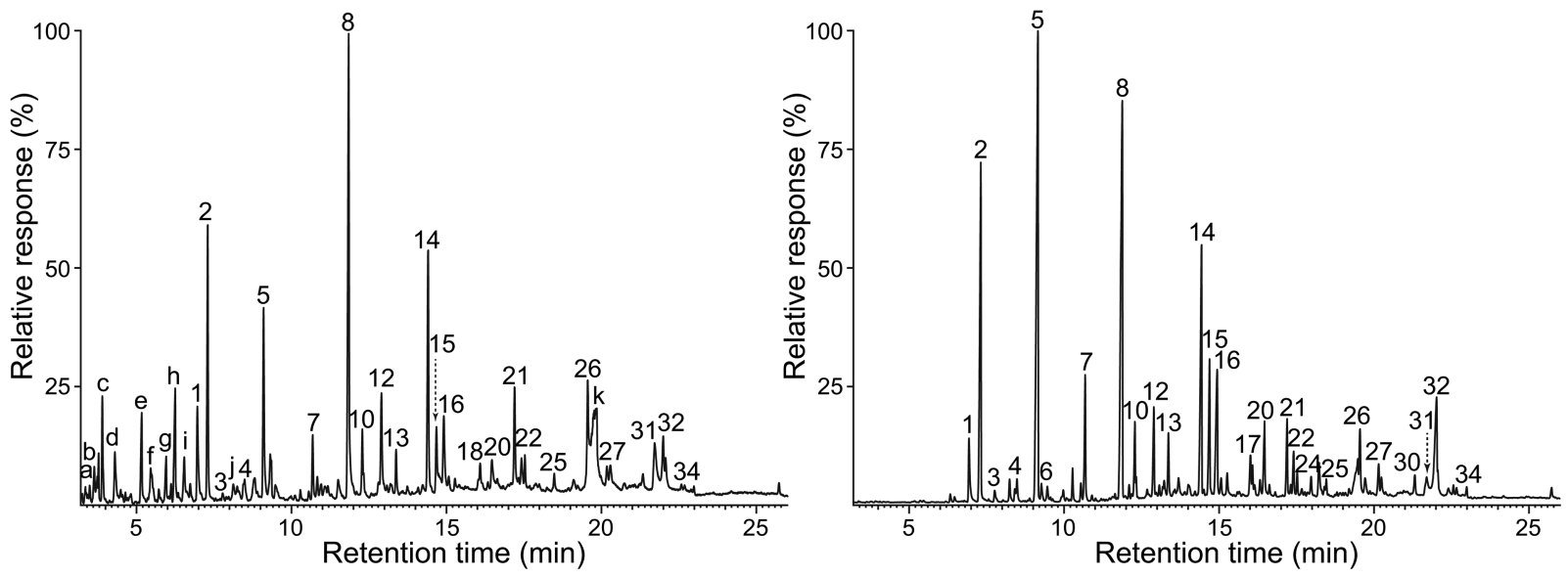

F Endocarp MWL
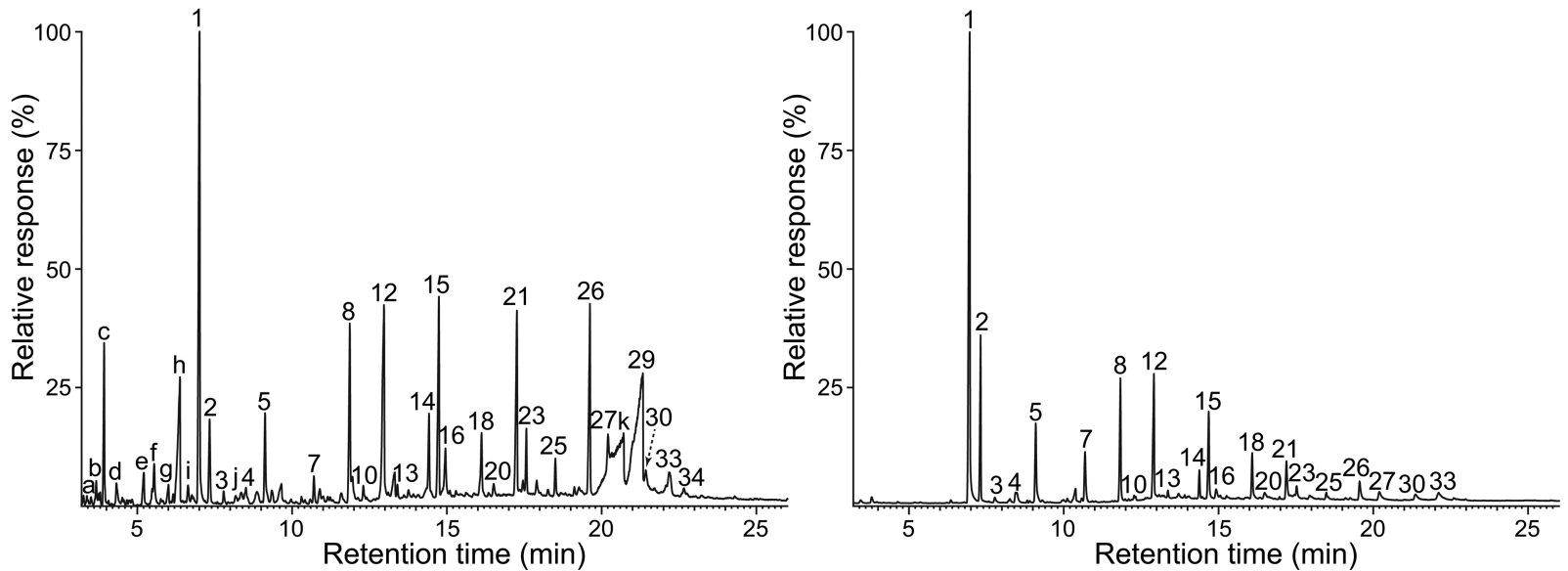

Figure 1. Py-GC/MS chromatograms of whole cell-walls (CWs) of the different macaúba parts (A) stalk, (B) epicarp, and (C) endocarp, and the MWLs isolated from (D) stalk, (E) epicarp, and (F) endocarp. The identities and relative abundances of the lignin-derived phenolic compounds released are listed in Table 1. Letters refer to carbohydrate compounds: $(3 H)$-furan-2-one (a); $(2 H)$-furan-3-one (b); furfural (c); 2hydroxymethylfuran (d); 2,3-dihydro-5-methylfuran-2-one (e); 5-methyl-2-furfuraldehyde (f); (5H)-furan-2-one (g); 4-hydroxy-5,6-dihydro-(2H)pyran-2-one (h); 2-hydroxy-3-methyl-2-cyclopenten-1-one (i); 3-hydroxy-2-methyl-(4H)-pyran-4-one (j); levoglucosan (k).

processing were performed using the LabSolution GPC software version 5.82 (Shimadzu, Kyoto, Japan). A kit of polystyrene standards 
Table 1. Identities and Relative Molar Abundances of the Lignin-Derived Phenolic Compounds Released after Py-GC/MS of the Different Macaúba Parts (CWs) and Their Isolated MWLs

\begin{tabular}{|c|c|c|c|c|c|c|c|}
\hline \multirow[b]{2}{*}{ no. } & \multirow[b]{2}{*}{ compound } & \multicolumn{2}{|c|}{ stalk } & \multicolumn{2}{|c|}{ fruit epicarp } & \multicolumn{2}{|c|}{ fruit endocarp } \\
\hline & & $\mathrm{CW}$ & MWL & $\mathrm{CW}$ & MWL & $\mathrm{CW}$ & MWL \\
\hline 1 & phenol & 17.7 & 21.8 & 6.8 & 3.3 & 24.8 & 51.3 \\
\hline 2 & guaiacol & 5.7 & 6.4 & 11.5 & 13.0 & 3.5 & 9.4 \\
\hline 3 & 4-methylphenol & 1.1 & 0.6 & 0.5 & 0.5 & 0.6 & 0.7 \\
\hline 4 & 3-methylphenol & 2.5 & 0.4 & 0.8 & 1.0 & 0.3 & 1.5 \\
\hline 5 & 4-methylguaiacol & 4.0 & 6.8 & 9.9 & 21.0 & 3.5 & 5.5 \\
\hline 6 & 4-ethylphenol & 0.5 & 0.3 & 0.5 & 0.8 & 0.3 & 0.0 \\
\hline 7 & 4-ethylguaiacol & 1.3 & 1.3 & 2.5 & 3.4 & 1.0 & 3.6 \\
\hline 8 & 4-vinylguaiacol & 14.5 & 10.7 & 19.7 & 15.6 & 7.0 & 5.4 \\
\hline 9 & 4-vinylphenol & 6.0 & 5.3 & 1.8 & 2.2 & 0.3 & 0.5 \\
\hline 10 & eugenol & 1.2 & 0.7 & 2.1 & 1.8 & 0.5 & 0.4 \\
\hline 11 & 4-propylguaiacol & 0.0 & 0.0 & 0.5 & 0.3 & 0.1 & 0.0 \\
\hline 12 & syringol & 7.4 & 7.8 & 4.0 & 2.4 & 8.4 & 6.3 \\
\hline 13 & cis-isoeugenol & 0.7 & 0.7 & 1.6 & 1.5 & 0.4 & 0.4 \\
\hline 14 & trans-isoeugenol & 3.6 & 2.3 & 9.3 & 7.7 & 2.8 & 1.2 \\
\hline 15 & 4-methylsyringol & 6.5 & 9.8 & 2.6 & 3.6 & 5.5 & 3.5 \\
\hline 16 & vanillin & 1.3 & 2.3 & 3.5 & 4.9 & 2.3 & 1.0 \\
\hline 17 & homovanillin & 0.0 & 0.0 & 0.3 & 1.2 & 0.3 & 0.0 \\
\hline 18 & 4-ethylsyringol & 1.9 & 1.4 & 0.8 & 0.5 & 1.4 & 2.2 \\
\hline 19 & vanillic acid methyl ester & 0.4 & 0.3 & 0.3 & 0.4 & 0.1 & 0.0 \\
\hline 20 & acetoguaiacone & 0.7 & 1.3 & 1.6 & 2.0 & 0.6 & 0.7 \\
\hline 21 & 4-vinylsyringol & 8.6 & 6.3 & 3.0 & 1.7 & 5.0 & 2.0 \\
\hline 22 & guaiacylacetone & 0.4 & 0.3 & 1.2 & 1.0 & 0.3 & 0.2 \\
\hline 23 & 4-allylsyringol & 1.6 & 1.2 & 0.7 & 0.4 & 1.2 & 0.3 \\
\hline 24 & propiovanillone & 0.3 & 0.3 & 0.3 & 0.4 & 0.6 & 0.0 \\
\hline 25 & cis-4-propenylsyringol & 1.5 & 1.2 & 0.7 & 0.3 & 0.9 & 0.4 \\
\hline 26 & trans-4-propenylsyringol & 5.8 & 4.0 & 3.5 & 1.6 & 4.6 & 1.0 \\
\hline 27 & syringaldehyde & 2.1 & 2.9 & 0.9 & 0.8 & 0.7 & 0.8 \\
\hline 28 & cis-coniferyl alcohol & 0.0 & 0.0 & 1.1 & 0.4 & 0.0 & 0.0 \\
\hline 29 & 4-hydroxybenzoic acid & 0.0 & 0.0 & 0.0 & 0.0 & 20.8 & 0.0 \\
\hline 30 & acetosyringone & 1.1 & 2.0 & 0.6 & 0.5 & 0.7 & 0.7 \\
\hline 31 & trans-coniferyl alcohol & 0.0 & 0.0 & 3.9 & 0.8 & 0.0 & 0.0 \\
\hline 32 & trans-coniferaldehyde & 0.0 & 0.0 & 2.5 & 4.4 & 0.5 & 0.0 \\
\hline 33 & syringylacetone & 1.3 & 1.1 & 0.9 & 0.4 & 0.9 & 0.8 \\
\hline \multirow[t]{5}{*}{34} & propiosyringone & 0.3 & 0.5 & 0.2 & 0.2 & 0.0 & 0.3 \\
\hline & $\mathbf{H}(\%)^{a}=$ & 7.7 & 2.3 & 2.5 & 3.0 & 2.9 & 4.6 \\
\hline & $\mathbf{G}(\%)^{a}=$ & 37.0 & 40.5 & 75.9 & 83.2 & 39.3 & 50.5 \\
\hline & $\mathbf{S}(\%)^{a}=$ & 55.3 & 57.2 & 21.7 & 13.8 & 57.9 & 44.8 \\
\hline & $\mathbf{S} / \mathbf{G}$ ratio $^{a}=$ & 1.5 & 1.4 & 0.2 & 0.2 & 1.5 & 0.9 \\
\hline
\end{tabular}

${ }^{a}$ Calculated without using phenol (1) and 4-hydroxybenzoic acid (29), arising from $p$-hydroxybenzoates, and 4-vinylphenol (9) and 4-vinylguaiacol (8), also arising from $p$-coumarates and ferulates, and the respective 4-vinylsyringol (21).

(Agilent Technologies, Stockport, United Kingdom), with $M_{\mathrm{r}}$ ranging from $5.8 \times 10^{2}$ up to $3.24 \times 10^{6} \mathrm{Da}$, were used to create the calibration curve.

\section{RESULTS AND DISCUSSION}

Three different lignified anatomical parts of the macaúba palm, namely stalks and the epicarp and endocarp from the fruit, were selected for this study. The Klason lignin content accounted for $30.1 \%$ (stalk), $18.0 \%$ (epicarp), and $39.8 \%$ (endocarp) of the dried material. The high lignin content found for the macaúba endocarp is in agreement with that observed in other palm fruit endocarps. ${ }^{5,39}$ These values greatly differ from those previously published that reported a considerably higher lignin content for the epicarp (up to $27.5 \%$ ) and a much lower lignin content (only 31.7\%) for the endocarp. ${ }^{1}$ The accuracies of these previously reported values, however, have to be dismissed due the large lignin contents reported for the pulp (29.3\%) and kernel (32.7\%), two nonlignified parts of the fruit that should not present much lignin content. Most probably, the lignin contents estimated previously were not corrected for the ash and protein present in the acid-insoluble lignin, which were corrected for in the present study. In addition, the crucible pore size is crucial for a precise determination, and this could be another reason for the discrepancies observed.

The composition and structure of the lignins in these three macaúba parts were analyzed "in situ" by Py-GC/MS and 2DNMR. To produce cleaner spectra, the MWLs were also isolated and subsequently analyzed by Py-GC/MS, 2D-NMR, DFRC, and GPC.

Lignin Composition of the Different Macaúba Parts as Determined by Py-GC/MS. The composition of the lignins in the different anatomical parts of macaúba was first analyzed in situ by $\mathrm{Py}-\mathrm{GC} / \mathrm{MS}$ that provides rough insight into 
A Stalk CW

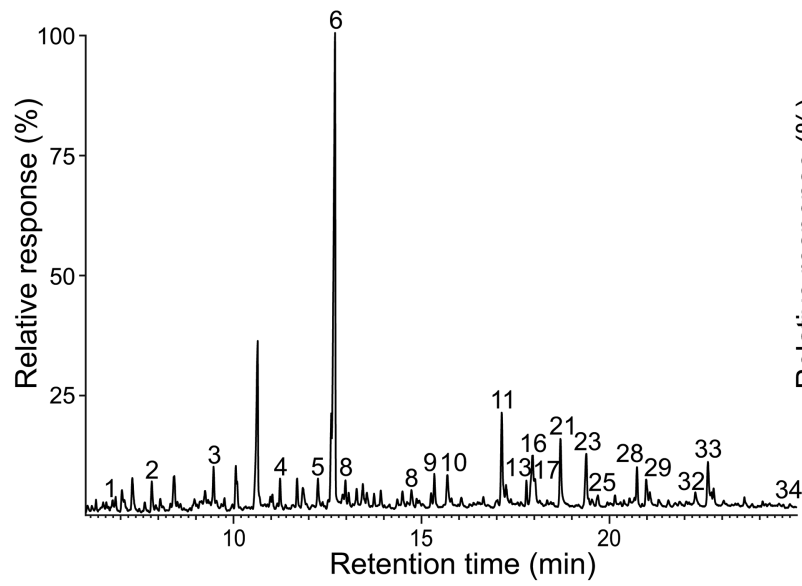

D Stalk MWL

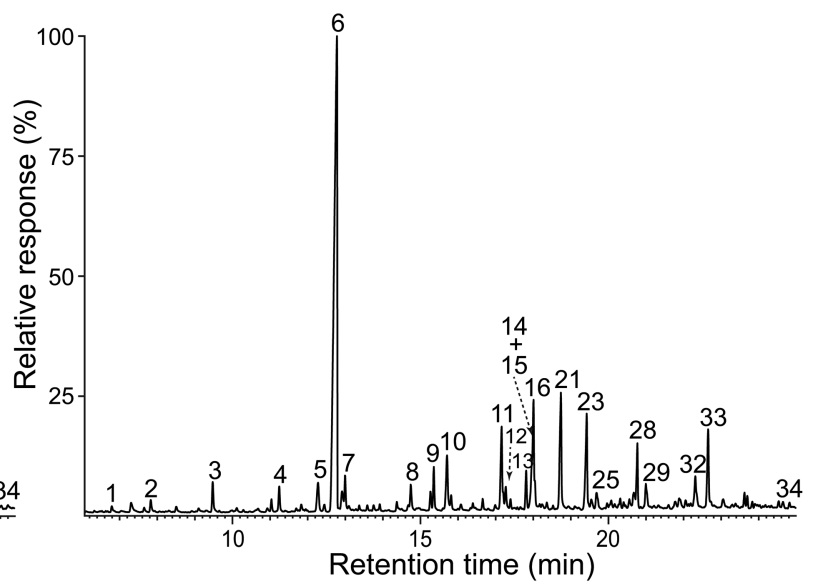

E Epicarp MWL

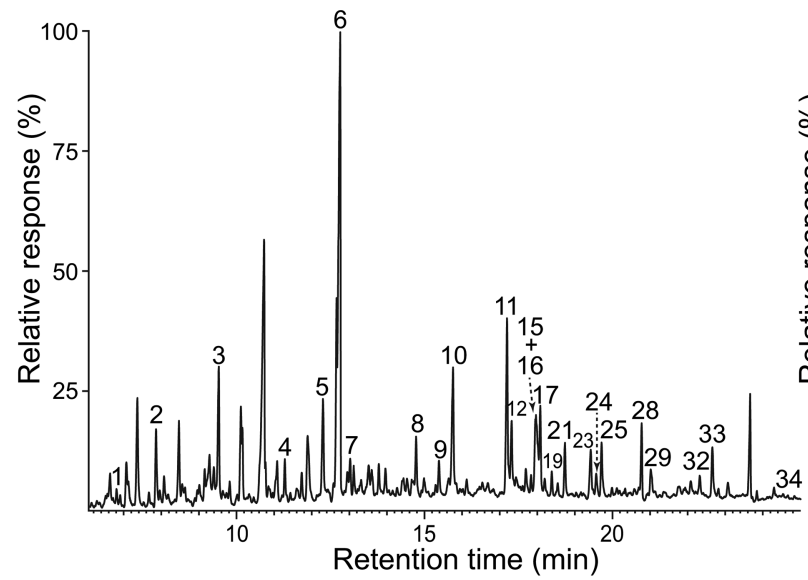

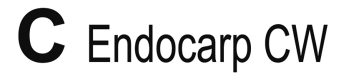

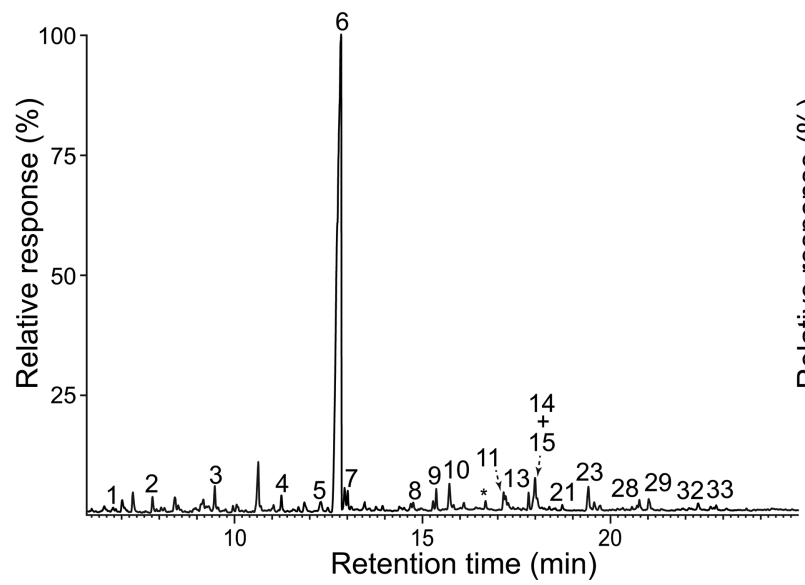

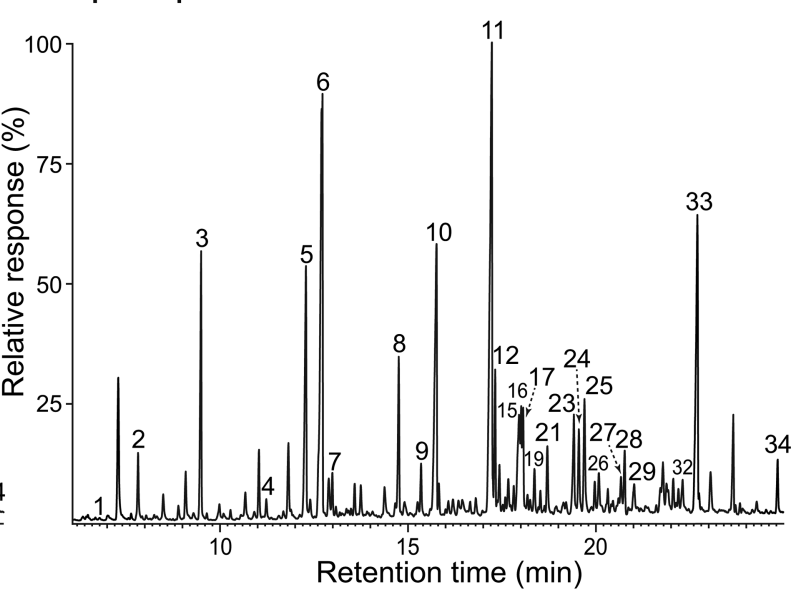

F Endocarp MWL

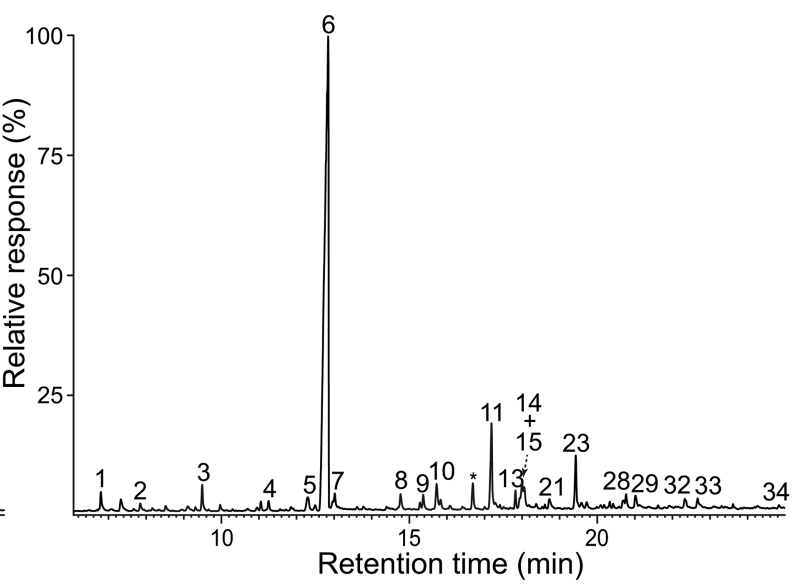

Figure 2. Py-(TMAH)-GC/MS chromatograms of whole cell-walls (CWs) of the different macaúba parts (A) stalk, (B) epicarp, and (C) endocarp and the MWLs isolated from (D) stalk, (E) epicarp, and (F) endocarp. The identities and relative abundances of the lignin-derived phenolic compounds released are listed in Table 2 .

the characteristics of the lignins. In addition, the respective isolated MWLs were also analyzed by Py-GC/MS. The pyrograms of the whole cell-walls (CWs) and their corresponding MWLs are shown in Figure 1. The identities and relative molar abundances of the released cell-wallassociated and lignin-derived phenolic compounds are listed in Table 1, whereas the identities of the carbohydrate-derived compounds are detailed in the legend of Figure 1. 
Table 2. Identities and Relative Molar Abundances of the Compounds Released after Pyrolysis in the Presence of TMAH of the Whole Cell Walls (CWs) and MWL Preparations Isolated from the Different Macaúba Parts

\begin{tabular}{|c|c|c|c|c|c|c|c|}
\hline \multirow[b]{2}{*}{ no. } & \multirow[b]{2}{*}{ compound } & \multicolumn{2}{|c|}{ stalk } & \multicolumn{2}{|c|}{ fruit epicarp } & \multicolumn{2}{|c|}{ fruit endocarp } \\
\hline & & $\mathrm{CW}$ & MWL & $\mathrm{CW}$ & MWL & $\mathrm{CW}$ & MWL \\
\hline 1 & methyl benzoate & 0.8 & 0.6 & 0.7 & 0.1 & 0.4 & 1.6 \\
\hline 2 & 1,2-dimethoxybenzene & 2.8 & 1.0 & 4.5 & 2.0 & 1.1 & 0.7 \\
\hline 3 & 3,4-dimethoxytoluene & 3.2 & 2.0 & 6.9 & 6.6 & 1.7 & 1.7 \\
\hline 4 & 1,2,3-trimethoxybenzene & 1.8 & 1.5 & 1.7 & 0.5 & 1.0 & 0.7 \\
\hline 5 & 3,4-dimethoxystyrene & 2.3 & 2.4 & 5.3 & 7.9 & 1.0 & 1.5 \\
\hline 6 & methyl 4-methoxybenzoate & 45.5 & 59.5 & 30.6 & 19.0 & 80.5 & 72.4 \\
\hline 7 & 3,4,5-trimethoxytoluene & 1.5 & 1.5 & 1.4 & 0.9 & 0.9 & 1.0 \\
\hline 8 & 1,2-dimethoxy-4-propenylbenzene & 1.4 & 0.1 & 2.8 & 3.6 & 0.4 & 1.1 \\
\hline 9 & 3,4,5-trimethoxystyrene & 2.0 & 0.1 & 1.3 & 1.1 & 1.0 & 0.8 \\
\hline 10 & 3,4-dimethoxybenzaldehyde & 2.8 & 0.1 & 7.5 & 11.1 & 2.0 & 2.0 \\
\hline 11 & methyl 3,4-dimethoxybenzoate & 6.4 & 0.2 & 7.9 & 17.1 & 0.8 & 4.9 \\
\hline 12 & 3,4-dimethoxyacetophenone & 1.5 & 0.0 & 3.6 & 2.8 & 0.7 & 0.4 \\
\hline 13 & 1-(3,4,5-trimethoxyphenyl)-1-propene & 1.3 & 0.1 & 0.6 & 0.5 & 0.7 & 0.7 \\
\hline 14 & cis-1-(3,4-dimethoxyphenyl)-2-methoxyethylene & 1.1 & 0.8 & 2.6 & 1.8 & 0.4 & 0.5 \\
\hline 15 & methyl 3,4-dimethoxybenzeneacetate & 1.8 & 0.8 & 2.9 & 2.1 & 0.4 & 0.4 \\
\hline 16 & 3,4,5-trimethoxybenzaldehyde & 3.3 & 5.6 & 1.6 & 2.1 & 1.9 & 1.6 \\
\hline 17 & trans-1-(3,4-dimethoxyphenyl)-2-methoxyethylene & 1.1 & 0.8 & 2.5 & 1.6 & 0.3 & 0.7 \\
\hline 18 & cis-1-(3,4-dimethoxyphenyl)-3-methoxyprop-1-ene & 0.0 & 0.0 & 0.6 & 0.3 & 0.0 & 0.0 \\
\hline 19 & cis-1-(3,4-dimethoxyphenyl)-1-methoxyprop-1-ene & 0.3 & 0.3 & 0.8 & 0.9 & 0.2 & 0.3 \\
\hline 20 & trans-1-(3,4-dimethoxyphenyl)-1-methoxyprop-1-ene & 0.1 & 0.2 & 0.5 & 0.4 & 0.2 & 0.1 \\
\hline 21 & methyl trans-4-O-methyl-p-coumarate & 5.4 & 7.2 & 2.2 & 1.5 & 0.0 & 0.6 \\
\hline 22 & 3,4,5-trimethoxyacetophenone & 1.7 & 1.6 & 1.0 & 0.7 & 0.8 & 0.3 \\
\hline 23 & methyl 3,4,5-trimethoxybenzoate & 2.6 & 3.7 & 1.2 & 1.7 & 0.8 & 2.4 \\
\hline 24 & methyl 4-O-methyl-dihydroferulate & 0.5 & 0.5 & 0.9 & 0.5 & 0.4 & 0.3 \\
\hline 25 & trans-1-(3,4-dimethoxyphenyl)-3-methoxyprop-1-ene & 0.8 & 1.2 & 2.2 & 0.9 & 0.3 & 0.3 \\
\hline 26 & threo-1-(3,4-dimethoxyphenyl)-1,2,3-trimethoxypropane & 0.3 & 0.3 & 0.2 & 0.4 & 0.1 & 0.2 \\
\hline 27 & erythro-1-(3,4-dimethoxyphenyl)-1,2,3-trimethoxypropane & 0.3 & 0.6 & 0.2 & 0.5 & 0.1 & 0.1 \\
\hline 28 & cis-1-(3,4,5-trimethoxyphenyl)-2-methoxyethylene & 1.2 & 0.2 & 1.0 & 0.6 & 0.4 & 0.6 \\
\hline 29 & trans-1-(3,4,5-trimethoxyphenyl)-2-methoxyethylene & 1.2 & 0.2 & 1.0 & 0.6 & 0.4 & 0.6 \\
\hline 30 & trans-1-(3,4,5-trimethoxyphenyl)-methoxyprop-1-ene & 0.6 & 1.1 & 0.4 & 0.2 & 0.3 & 0.2 \\
\hline 31 & cis-1-(3,4-dimethoxyphenyl)-2,3-dimethoxyprop-1-ene & 0.0 & 0.2 & 0.3 & 0.1 & 0.0 & 0.0 \\
\hline 32 & cis-1-(3,4-dimethoxyphenyl)-2,3-dimethoxyprop-1-ene & 1.1 & 1.6 & 0.7 & 0.7 & 0.4 & 0.5 \\
\hline 33 & methyl trans-4-O-methyl-ferulate & 3.1 & 3.7 & 2.2 & 8.5 & 0.2 & 0.5 \\
\hline 34 & methyl trans-4-O-methyl-sinapate & 0.3 & 0.3 & 0.1 & 0.9 & 0.1 & 0.2 \\
\hline
\end{tabular}

Among the phenolic compounds, the pyrograms of the CWs and their isolated MWLs showed compounds derived from the p-hydroxyphenyl (H), guaiacyl (G), and syringyl (S) lignin units such as phenol 1, guaiacol 2, 4-methylguaiacol 5, 4ethylguaiacol 7, 4-vinylguaiacol 8, 4-vinylphenol 9, eugenol 10, syringol 12, trans-isoeugenol 14, 4-methylsyringol 15, vanillin 16, 4-ethylsyringol 18, 4-vinylsyringol 21, trans-4-propenylsyringol 26, syringaldehyde 27 , and acetosyringone 30 , among others. In general terms, the profile of the lignin peaks in the pyrograms of the CWs matched those present in the pyrograms of the MWLs. Important differences were observed in the composition of the lignins among the different macaúba parts. High levels of phenol, 1, were released from the stalks (17.7\% and $21.8 \%$ of all phenolic compounds in CW and its MWL) and, particularly, from the endocarp (24.8\% and $51.3 \%$ in CW and its MWL), whereas lower amounts were released from the epicarp (6.8\% and 3.3\% in CW and its MWL). This might be an indication of the occurrence of important amounts of $p$-hydroxybenzoates in these lignins, which decarboxylate

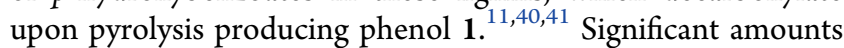
of intact 4-hydroxybenzoic acid 29, were also released from the endocarp cell walls (20.8\% of all phenolics) illustrating the importance of $p$-hydroxybenzoates $\mathbf{p} \mathbf{B A}$ in this particular issue.
It is evident then that the relative abundance of phenol 1, cannot be used here for an accurate estimation of the lignin H:G:S composition as the major part of it does not arise from H-lignin units but from $p$-hydroxybenzoates. Likewise, 4vinylphenol 9, and 4-vinylguaiacol 8 , might also arise from $p$ coumarates $p \mathbf{C A}$ and ferulates FA upon decarboxylation during pyrolysis, as also occurs in the lignins from other plants; ${ }^{15,31,40}$ 4-vinylsyringol 21, may also arise from sinapates although such esters have been only rarely characterized in plant cell wall material, an exception being in wild rice. ${ }^{42}$ Therefore, determining the lignin composition and $\mathbf{S} / \mathbf{G}$ ratios in these plant materials by $\mathrm{Py}-\mathrm{GC} / \mathrm{MS}$ is a difficult task. A rough estimation of the H:G:S composition was made without using phenol 1, or 4-hydroxybenzoic acid 29, nor 4-vinylphenol 9, and 4-vinylguaiacol $\mathbf{8}$, nor the respective 4-vinylsyringol $\mathbf{2 1}$ (Table 1). The lignin composition thus estimated indicated that the lignin from stalks was slightly enriched in S-lignin units (S/G around 1.4-1.5), whereas the lignin from the epicarp is highly enriched in $\mathbf{G}$-lignin ( $\mathbf{S} / \mathbf{G}$ of 0.2 ), and the endocarp lignin presents an intermediate $\mathbf{S} / \mathbf{G}$ ratio of around $0.9-1.5$.

The occurrence of $p$-hydroxybenzoates $p \mathbf{B A}$ (as well as benzoates $\mathbf{B A}, p$-coumarates $p \mathbf{C A}$, ferulates FA, and sinapates SA) in the lignins of the different macaúba fruit parts was 

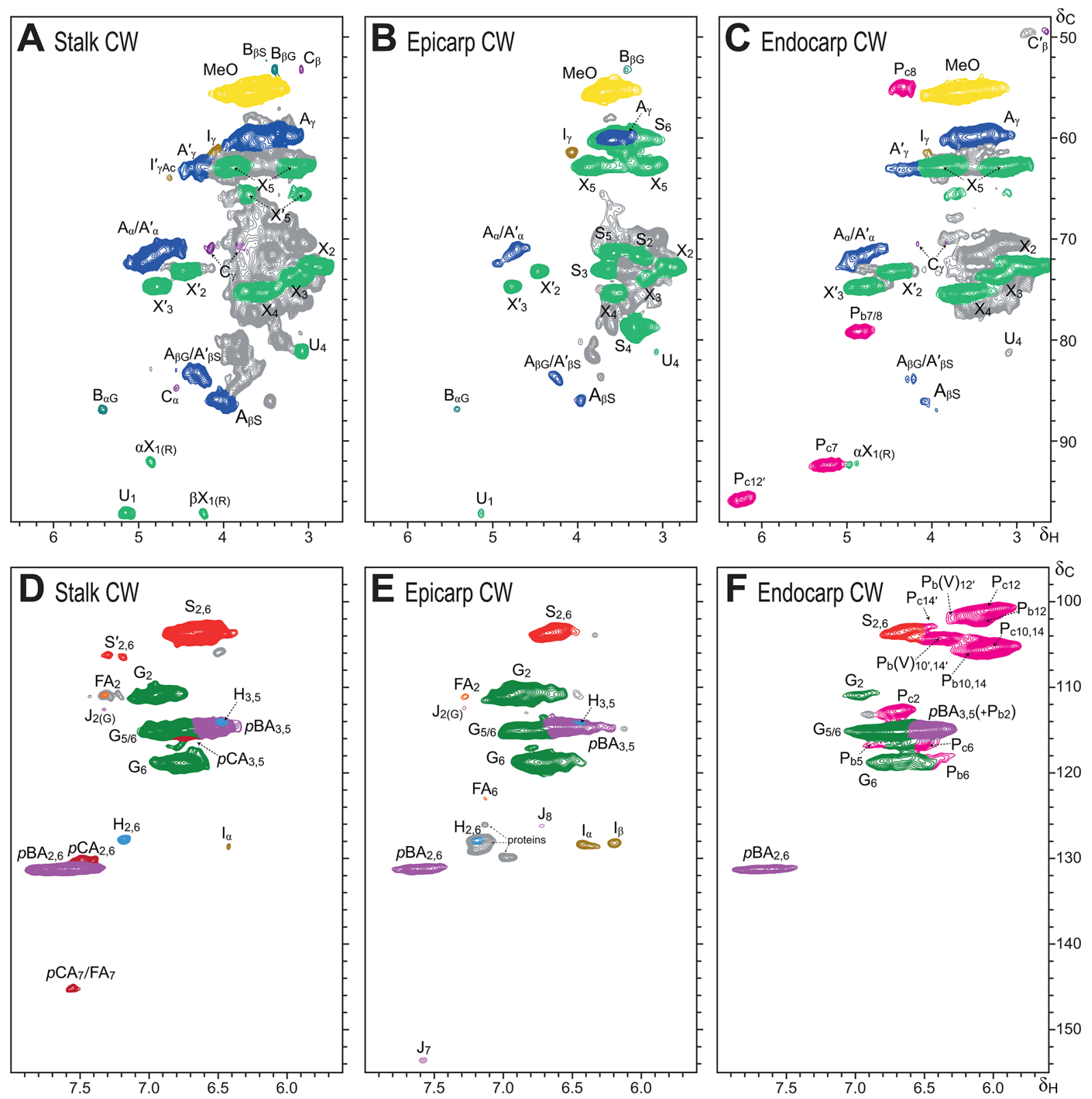

Figure 3. Side-chain $\left(\delta_{\mathrm{C}} / \delta_{\mathrm{H}} 48-98 / 2.6-6.5\right.$, top $)$ and aromatic $\left(\delta_{\mathrm{C}} / \delta_{\mathrm{H}} 96-155 / 5.6-8.0\right.$, bottom $)$ regions of the $2 \mathrm{D}$ HSQC NMR spectra of the whole cell-walls (CWs) from (A) macaúba stalk, (B) macaúba fruit epicarp, and (C) macaúba fruit endocarp. The lignin and carbohydrate signal assignments are listed in Tables S1 and S2. The main lignin structures identified are depicted in Figure 5.

demonstrated by pyrolysis in the presence of TMAH as a methylating reagent (Figure 2). The identities of the compounds released upon $\mathrm{Py} / \mathrm{TMAH}$ and their relative abundances are listed in Table 2. Py/TMAH prevents decarboxylation and results in depolymerization and subsequent methylation of the phenolic and carboxyl groups. $^{11,15,31,40}$ Thus, Py/TMAH released high levels of the fully methylated derivative of $p$-hydroxybenzoic acid $p \mathbf{B A}$ (methyl 4-methoxybenzoate 6) that was particularly abundant in the lignins from stalks and endocarp and confirmed the occurrence of high amounts of $p$-hydroxybenzoates $p \mathbf{B A}$ in all these lignins, as also occurs in the lignins of other palms. ${ }^{11,12,41}$ Significant amounts of the methylated derivatives of $p$ coumarate $p \mathbf{C A}$ and ferulate FA, namely methyl trans-4-Omethyl-p-coumarate 21, and methyl trans-4-O-methyl-ferulate 33, were also observed in the lignins of stalks and epicarp but were barely detected in the lignin from the endocarp. Minor amounts of the methylated derivative of sinapate SA (methyl trans-4-O-methyl-sinapate 34) could be also found in the epicarp lignin, and in trace amounts in the stalk and endocarp lignins. $p$-Hydroxybenzoates $p \mathbf{B A}$ and $p$-coumarates $p \mathbf{C A}$ are mostly found acylating the $\gamma-\mathrm{OH}$ of the lignin side-chains, and preferentially on S-lignin units, ${ }^{9,11,12,43}$ whereas ferulates and sinapates acylate cell-wall polysaccharides, with the ferulate FA in particular participating in both polysaccharide-polysaccharide and lignin-polysaccharide cross-coupling reactions.' However, the presence of relatively higher amounts of ferulates in the isolated lignin from epicarp in comparison to its respective whole cell walls suggests that ferulates FA are not only acylating the carbohydrates but may also be participating as lignin structural units during epicarp lignification. Interestingly, we also noted the release of minor amounts of methyl benzoate BA, a compound that was recently described 

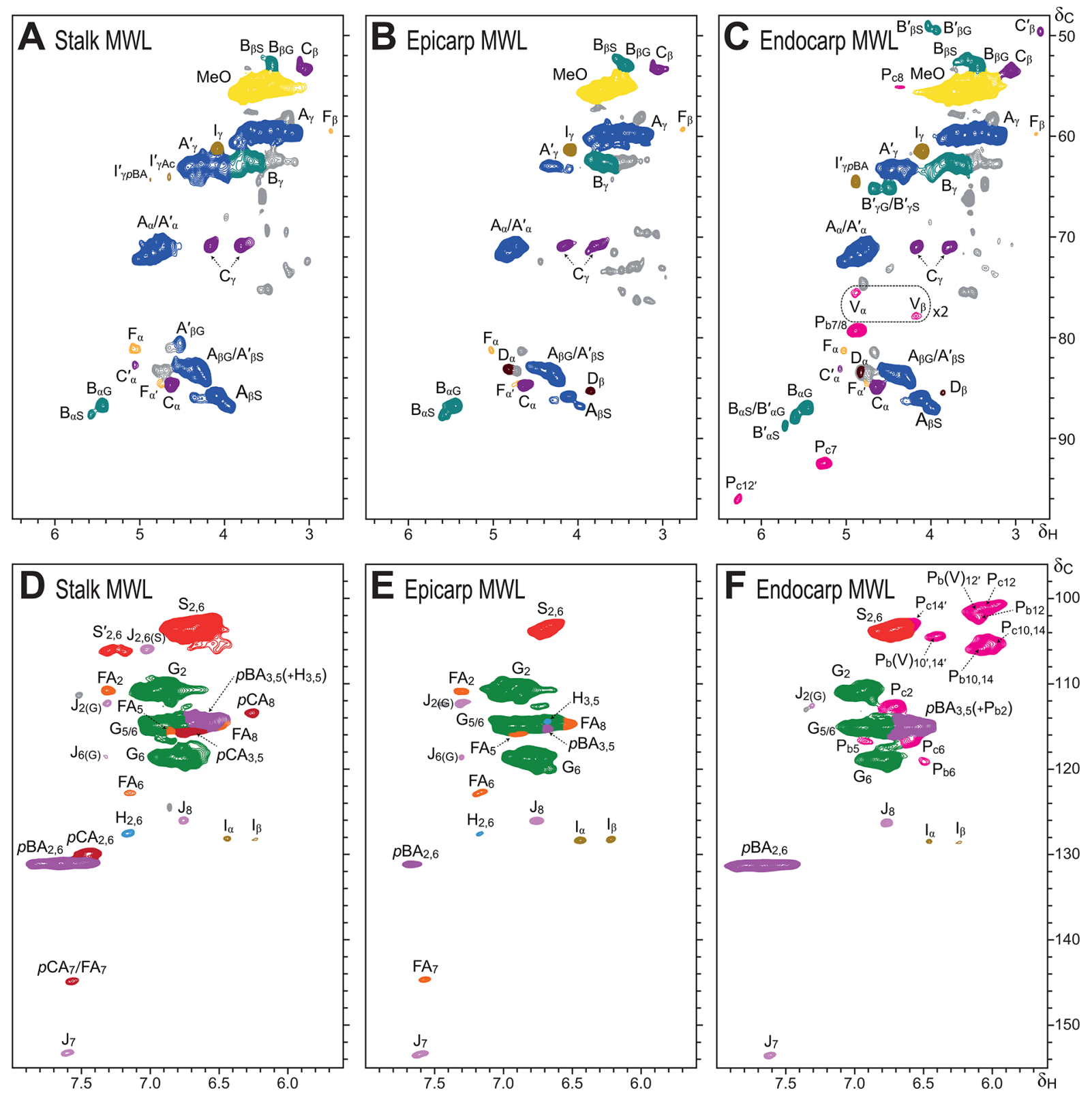

Figure 4. Side-chain $\left(\delta_{\mathrm{C}} / \delta_{\mathrm{H}} 48-98 / 2.6-6.5\right.$, top $)$ and aromatic $\left(\delta_{\mathrm{C}} / \delta_{\mathrm{H}} 96-155 / 5.6-8.0\right.$, bottom $)$ regions from the 2D HSQC NMR spectra of the MWLs isolated from (A) macaúba stalk, (B) macaúba fruit epicarp, and (C) macaúba fruit endocarp. The signal assignments are listed in Table S1. The main lignin structures identified are depicted in Figure 5.

to be also attached to the $\gamma$-OH of the lignin side-chain in other palms. $^{44}$

Polysaccharides and Lignin Structural Units in the Cell Walls of the Different Macaúba Parts, as Elucidated by $2 \mathrm{D}-\mathrm{NMR}$. The whole cell-walls of the three macaúba parts were analyzed in situ by gel state $2 \mathrm{D}-\mathrm{NMR},{ }^{35,36}$ and the spectra were compared with those of their corresponding isolated MWLs. The side-chain $\left(\delta_{\mathrm{C}} / \delta_{\mathrm{H}} 48-98 / 2.6-6.5\right)$ and the aromatic/unsaturated $\left(\delta_{\mathrm{C}} / \delta_{\mathrm{H}} 96-155 / 5.6-8.0\right)$ regions of the HSQC spectra of the whole cell-walls and their isolated MWLs are shown in Figures 3 and 4. The spectra of the whole cell-walls showed signals from carbohydrates and lignin, whereas the spectra of the isolated MWLs showed mostly signals from the lignin polymer. The lignin correlation signals assigned in the HSQC spectra are listed in Table S1 whereas the main carbohydrate signals are detailed in Table S2. The main lignin substructures identified are depicted in Figure 5.
Polysaccharides. The HSQC spectra of the whole-cell-wall materials revealed notable differences in the composition of carbohydrates in the three macaúba parts, which are observed in two separate regions, in the aliphatic-oxygenated region (Figure $3 \mathrm{~A}-\mathrm{C}$ ) and, especially, in the region corresponding to the correlations of the anomeric carbons (Figure 6). Polysaccharide signals were dominated by hemicelluloses and noncrystalline carbohydrates as cellulose signals cannot be seen at the gel state due to their crystallinity. ${ }^{35}$ In the aliphaticoxygenated region (Figure $3 \mathrm{~A}-\mathrm{C}$ ), the main carbohydrate signals corresponded to $\mathrm{C}_{2} / \mathrm{H}_{2}, \mathrm{C}_{3} / \mathrm{H}_{3}, \mathrm{C}_{4} / \mathrm{H}_{4}$, and $\mathrm{C}_{5} / \mathrm{H}_{5}$ correlations of xylans $\left(\beta\right.$-D-xylopyranoside $\left.\mathbf{X}_{2}, \mathbf{X}_{3}, \mathbf{X}_{4}, \mathbf{X}_{5}\right)$, including $O$-acetylated xylans (2-O-acetyl- $\beta$-D-xylopyranoside $\mathbf{X}^{\prime}{ }_{2}$ and 3-O-acetyl- $\beta$-D-xylopyranoside $\left.\mathbf{X}^{\prime}{ }_{3}\right)$, and the $\mathrm{C}_{4} / \mathrm{H}_{4}$ correlation for 4-O-methyl- $\alpha$-D-glucuronic acid $\left(\mathrm{U}_{4}\right)$. Xylans were particularly abundant in the cell walls of stalks and endocarp. By contrast, the spectrum of epicarp was dominated 
<smiles>COc1cc(C(O)C(O)C2Oc3c(OC)cc(C(C)C)cc3OC2C)cc(C)c1OC</smiles>

A

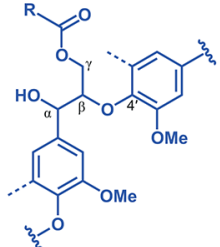

$A^{\prime}$

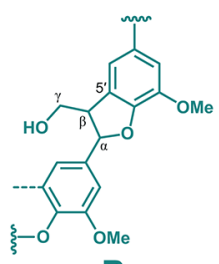

B

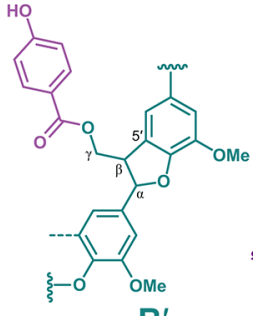

B'

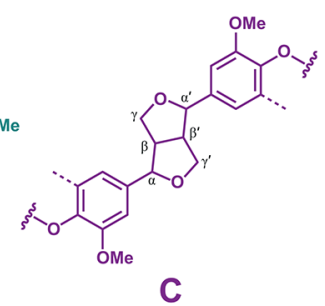

C

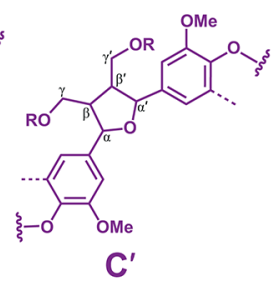

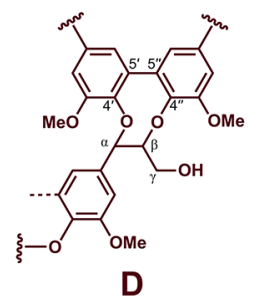

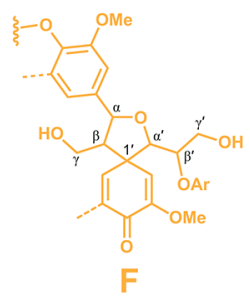

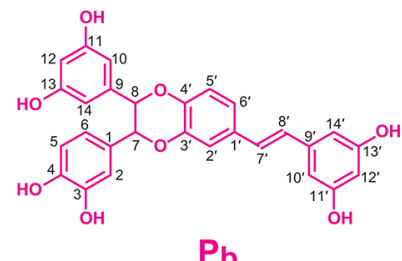

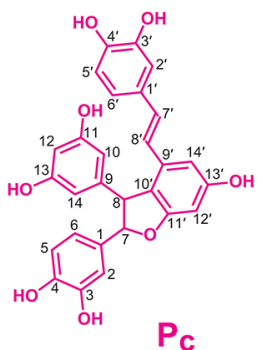<smiles>Cc1cc(C2Oc3cc(/C=C/c4cc(O)cc(O)c4)ccc3OC2CO)cc(O)c1O</smiles><smiles>COc1ccc(/C=C/CO)cc1OC</smiles><smiles>[2H]C(=O)OC/C=C/c1ccc(OC(F)(F)F)c(OC)c1</smiles><smiles>COc1cc(O)c(C=CC=O)cc1OC</smiles><smiles>CC(C)(C)Oc1ccc2c(c1)OCOC2=O</smiles><smiles>CC(=O)OCCOc1ccc(C=CC(C)C)cc1</smiles><smiles>CCOc1ccc(-c2c[Y]oc(=O)c2)cc1[N+](=O)[O-]</smiles><smiles>CC(C)Oc1ccc(C(C)O)cc1</smiles><smiles>CCOc1ccc(C(C)C)cc1OCC</smiles><smiles>CCOc1c(OC)cc(C(O)C(C)C)cc1OC</smiles><smiles>CCOc1cc(C(=O)CC)cc(OC)c1OCC</smiles>

Figure 5. Main structures present in the lignins of macaúba as identified in the 2D HSQC NMR spectra of Figures 3 and 4 . A: $\beta$-ethers; $\mathbf{A}^{\prime}: \beta$-ether structures with acylated (by acetate, benzoate, $p$-hydroxybenzoate, or $p$-coumarate) $\gamma$-OH; $\mathbf{B}$ : phenylcoumaran; $\mathbf{B}^{\prime}$ : phenylcoumarans with $p$ hydroxybenzoates acylating the $\gamma-\mathrm{OH} ; \mathbf{C}$ : resinols; $\mathbf{C}^{\prime}$ : tetrahydrofuran structures formed by $\beta$ - $\beta^{\prime}$-coupling of monolignols acylated at the $\gamma$-OH; $\mathbf{D}$ : dibenzodioxocins; F: spirodienones; $\mathbf{P}_{\mathrm{b}}$ : benzodioxane-type piceatannol dimeric structures; $\mathbf{P}_{\mathrm{c}}$ : phenylcoumaran-type piceatannol dimeric structures; V: benzodioxane structures formed by cross-coupling of piceatannol and a monolignol; I: cinnamyl alcohol end-groups; $\mathbf{I}^{\prime}$ : cinnamyl alcohol end-groups acylated at the $\gamma-\mathrm{OH} ; \mathrm{J}$ : cinnamaldehyde end-groups; $p \mathbf{B A}$ : $p$-hydroxybenzoates; $p \mathbf{C A}$ : $p$-coumarates; FA: ferulates; $\mathbf{H}$ : $p$ hydroxyphenyl units; G: guaiacyl units; $S$ : syringyl units; $S^{\prime}$ : $C \alpha$-oxidized syringyl units;. The structures are colored to match the assigned contours in the NMR spectra in Figures 3 and 4.

by strong signals corresponding to the $\mathrm{C}_{2} / \mathrm{H}_{2}, \mathrm{C}_{3} / \mathrm{H}_{3}, \mathrm{C}_{4} / \mathrm{H}_{4}$, $\mathrm{C}_{5} / \mathrm{H}_{5}$, and $\mathrm{C}_{6} / \mathrm{H}_{6}$ correlations of $\alpha$-1,4-glucans (starch $\mathrm{S}_{2}, \mathrm{~S}_{3}$, $\left.\mathbf{S}_{4}, \mathbf{S}_{5}, \mathbf{S}_{6}\right)$. The carbohydrate signals observed in the anomeric region of the spectra also showed differences among the three macaúba parts (Figure 6). Cross-signals from xylans $\left(\mathbf{X}_{1}\right.$, $\boldsymbol{\alpha} \mathbf{X}_{1(\mathrm{R})}$, and $\left.\boldsymbol{\beta} \mathbf{X}_{1(\mathrm{R})}\right)$ and $\beta$-glucans, including noncrystalline cellulose $\left(\mathbf{G l}_{1}\right)$, together with signals from $O$-acetylated xylans $\left(\mathbf{X}_{1}^{\prime}\right)$, and from the 4-O-methyl- $\alpha$-D-glucuronic acid $\left(\mathbf{U}_{1}\right)$ were observed in the spectra of all macaúba samples. In addition, signals from arabinans $\left(\mathbf{A r}_{1}\right.$ and $\left.\mathbf{A r}_{1(\mathrm{~T})}\right)$, galactans $\left(\mathbf{G a}_{1}\right)$, and mannans $\left(\mathbf{M}_{1}\right)$, including $O$-acetylated mannans $\left(\mathbf{M}^{\prime}{ }_{1}\right)$, were also observed in the cell walls of stalks and epicarp. As observed in the aliphatic-oxygenated region, the anomeric region of the epicarp spectrum was also largely dominated by a strong signal from $\alpha$-1,4-glucans ( $\operatorname{starch} S_{1}$ ). These spectra therefore revealed that the stalks and the endocarp were enriched in xylans (including acetylated xylans), whereas the epicarp also presented xylans but important amounts of nonstructural $\alpha$-1,4-glucan polymers (starch). Pectic polysaccharides (arabinans and galactans) occurred in the stalks and epicarp but were absent in the endocarp.

Lignin Structural Units. The aromatic region of the HSQC spectra gave information regarding the composition of the different aromatic units (Figures $3 \mathrm{D}-\mathrm{F}$ and $4 \mathrm{D}-\mathrm{F}$ ). The main signals corresponded to the aromatic rings of the different $\mathbf{H}$-,
G-, and S-lignin units. Signals of $\mathbf{H}$-lignin units were only detected in the HSQC spectra of the stalks and epicarp; the relatively high content of apparent $\mathbf{H}$-lignin in the cell walls of epicarp (Figure 3E) was mostly due to proteins, which were removed during MWL isolation (Figure 4E). Strong signals from $p$-hydroxybenzoates $p \mathbf{B A}$ were found in all three lignins, being particularly abundant in the lignin from stalks and endocarp, and at lower levels in the lignin from epicarp, corroborating the Py/TMAH data. Likewise, minor amounts of $p$-coumarates $p \mathbf{C A}$ and ferulates FA were also found in the lignins from stalks and epicarp, in agreement with Py/TMAH results. $p$-Hydroxybenzoates $p \mathbf{B A}$ and $p$-coumarates $p \mathbf{C A}$ are found acylating the $\gamma-\mathrm{OH}$ of the side-chain in the lignins of many plants, $9,11,12,16,43-45$ whereas ferulates FA are usually found acylating carbohydrates. ' However, and as indicated above, the significant amounts of ferulates FA in the MWLs isolated from epicarp, in comparison with the whole cell walls, seems to indicate that they are not only attached to carbohydrates but that they are also part of the lignin network.

Identification of Piceatannol Units Incorporated into the Endocarp Lignin. The most remarkable feature in the aromatic region of the HSQC spectra was the presence of a group of strong signals (labeled $\mathbf{P}_{\mathbf{b}}$ and $\mathbf{P}_{\mathbf{c}}$ and $\mathbf{V}$ ) that appeared only in the endocarp spectra (Figures $3 \mathrm{~F}$ and $4 \mathrm{~F}$ ) and that were assigned to piceatannol-derived units. Piceatannol is a member 

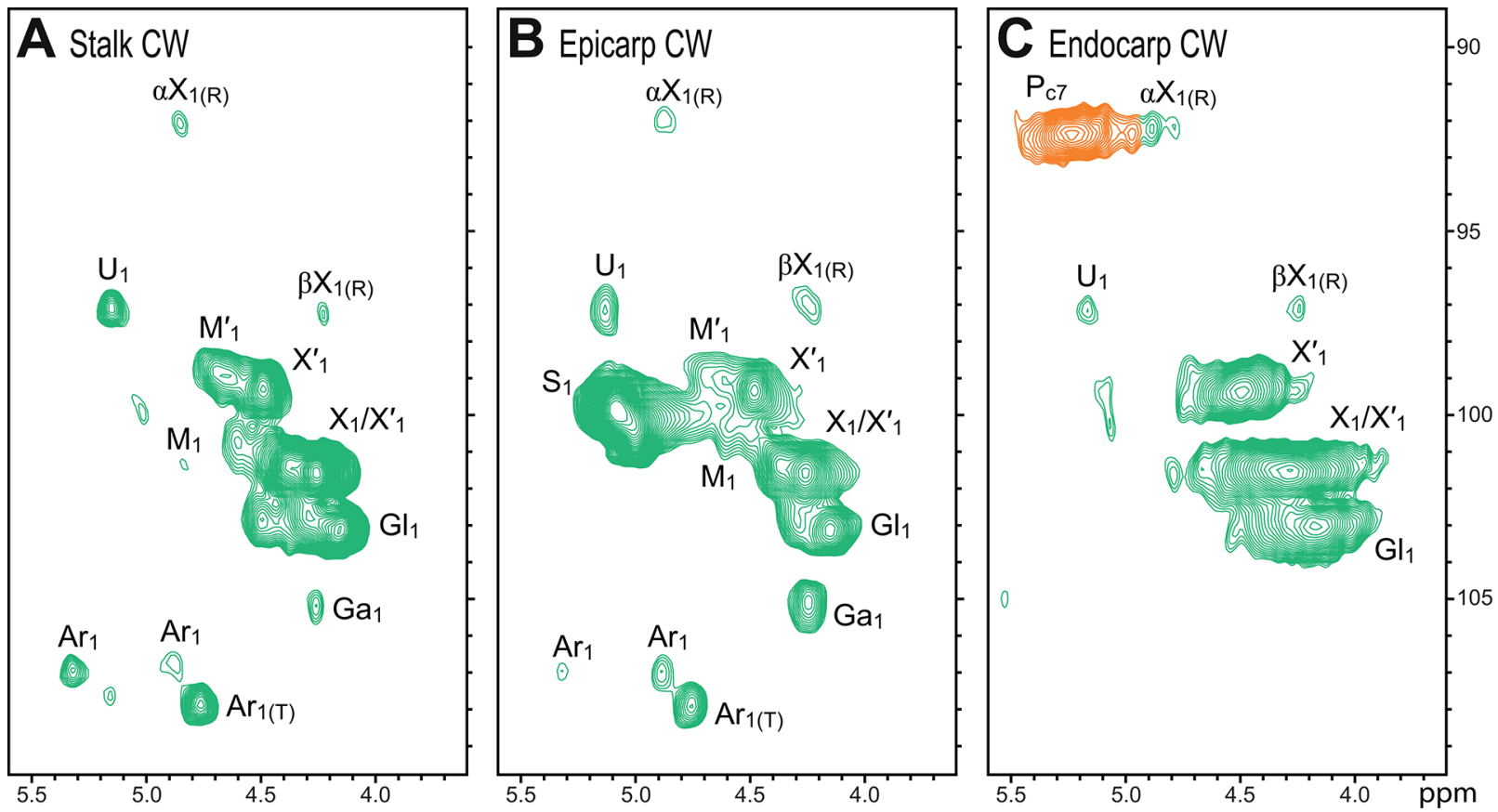

Figure 6. Carbohydrate anomeric regions $\left(\delta_{\mathrm{C}} / \delta_{\mathrm{H}} 89-110 / 3.5-5.6\right)$ of the $2 \mathrm{D}$ HSQC NMR spectra of the whole cell walls of the different macaúba parts, (A) stalk, (B) epicarp, and (C) endocarp, after forming a gel in DMSO- $d_{6}$. The assignments of the carbohydrate signals are listed in Table S2.

of the polyphenolic hydroxystilbenes, a family of plant secondary metabolites, with antiviral, antibacterial, and antioxidant properties that are known to contribute to plant disease resistance. ${ }^{46,47}$ The signals for piceatannol in the HSQC spectra were assigned by the aid of an authentic piceatannol standard, certain dehydrodimers, and from the products of biomimetic polymerization reactions, as already reported. ${ }^{5}$ The signals corresponding to piceatannol units were labeled as $\mathbf{P}_{\mathbf{b}}$ (piceatannol units involved in benzodioxane structures), $\mathbf{P}_{\mathbf{c}}$ (piceatannol units involved in phenylcoumaran structures), and $\mathbf{V}$ (piceatannol units involved in benzodioxane structures formed by cross-coupling with monolignols) corresponding to different piceatannol coupling structures, as already described. ${ }^{5}$ Piceatannol consists of two dihydroxylated aromatic rings joined by an ethylene bridge; one of the aromatic rings presents two hydroxyl groups in meta-positions (a resorcinol unit) whereas the other ring presents two hydroxyl groups in ortho positions (a catechol unit). The $\mathrm{C}_{10,14} / \mathrm{H}_{10,14}$ and $\mathrm{C}_{12} / \mathrm{H}_{12}$ correlation signals for the resorcinol part (labeled $\mathbf{P}_{\mathbf{b} 10^{\prime}, 14^{\prime}}, \mathbf{P}_{\mathbf{b} 10,14}, \mathbf{P}_{\mathbf{c 1 0}, 14}, \mathbf{P}_{\mathbf{b} 12^{\prime}}, \mathbf{P}_{\mathbf{b} 12}$, and $\mathbf{P}_{\mathbf{c} 12}$ ) are the most prominent ones and appear in the upper part of the aromatic region, whereas the $\mathrm{C}_{2} / \mathrm{H}_{2}, \mathrm{C}_{5} / \mathrm{H}_{5}$, and $\mathrm{C}_{6} / \mathrm{H}_{6}$ correlation signals for the catechol part (labeled $\mathbf{P}_{\mathbf{b} 2}, \mathbf{P}_{\mathrm{c} 2}, \mathbf{P}_{\mathrm{b} 5}$, $\mathbf{P}_{\mathbf{b} 6}$, and $\mathbf{P}_{\mathbf{c} 6}$ ) are present downfield in the spectra (Figures $3 \mathrm{~F}$ and $4 \mathrm{~F})$. The assignments of all these signals involving piceatannol units are detailed in Table S1. Interestingly, piceatannol was exclusively present in the lignin from macaúba endocarp, indicating its exclusive direction to this pericarp layer. Piceatannol was also found incorporated into the lignins of other palm fruit endocarps, such as in carnauba (Copernicia prunifera) and coconut (Cocos nucifera). ${ }^{5}$ Piceatannol is mainly incorporated into the lignin moiety through condensed linkages, forming benzodioxane and phenylcoumaran structures, that may contribute to producing an extremely hard and rigid endocarp compared to stalk and epicarp.
Lignin Interunit Linkages. The aliphatic-oxygenated region of the spectra of whole cell walls (Figure 3 ) and their isolated MWLs (Figure 4) provided useful information about the types of interunit linkages present in the lignins from the different macaúba parts. In this region, typical signals from lignin included signals from side-chains in $\beta$-ether $\mathbf{A}$, phenylcoumaran $\mathbf{B}$, resinol $\mathbf{C}$, dibenzodioxocin $\mathbf{D}$, spirodienone $\mathbf{F}$, and cinnamyl alcohol end-group I structures. In addition to the typical lignin signals, other "novel" signals from structures involving piceatannol $\left(\mathbf{P}_{\mathrm{b}}, \mathbf{P}_{\mathfrak{c}}\right.$, and $\left.\mathbf{V}\right)$ were observed in the endocarp spectra (Figures $3 \mathrm{C}$ and $4 \mathrm{C}$ ). The definitive identification of the new structures involving piceatannol were attained by HSQC-TOCSY and HMBC experiments and radical coupling model studies, as already described. ${ }^{5}$ Thus, $\mathbf{P}_{\mathbf{b}}$ signals corresponded to a benzodioxane structure that was formed by the 8-O-4' radical coupling of two piceatannol units followed by internal trapping of the quinone methide intermediate by the $3^{\prime}-\mathrm{OH}$ and subsequent rearomatization forming the benzodioxane bridge; on the other hand, $\mathbf{P}_{\mathbf{c}}$ signals corresponded to a phenylcoumaran structure formed by $8-10^{\prime}$ radical coupling of two piceatannol units followed by internal trapping of the $11^{\prime}-\mathrm{OH}$ by the quinone methide intermediate and subsequent rearomatization. Finally, $\mathbf{V}$ signals corresponded to a benzodioxane structure formed via $\beta-O-4^{\prime}$ radical coupling of a monolignol (at its $\beta$-position) and the catechol part of piceatannol (at its $4^{\prime}-O$ position) followed by internal trapping of the quinone methide intermediate by the $3^{\prime}-\mathrm{OH}$ and forming the benzodioxane bridge. The occurrence of these structures conclusively establishes that piceatannol is a real lignin monomer participating in coupling and cross-coupling reactions during endocarp lignification.

Extent and Nature of Lignin Acylation. The HSQC spectra (Figures 3 and 4) also revealed the presence of characteristic signals for $\gamma$-acylated $\beta$-ethers $\mathbf{A}^{\prime}$ and other structures $\left(\mathbf{B}^{\prime}\right.$ and $\left.\mathbf{I}^{\prime}\right)$. In addition, signals for the $\mathrm{C}_{\alpha} / \mathrm{H}_{\alpha}$ and $\mathrm{C}_{\beta} / \mathrm{H}_{\beta}$ correlations of a tetrahydrofuran substructure $\mathbf{C}^{\prime}$, arising from $\beta-\beta^{\prime}$ 

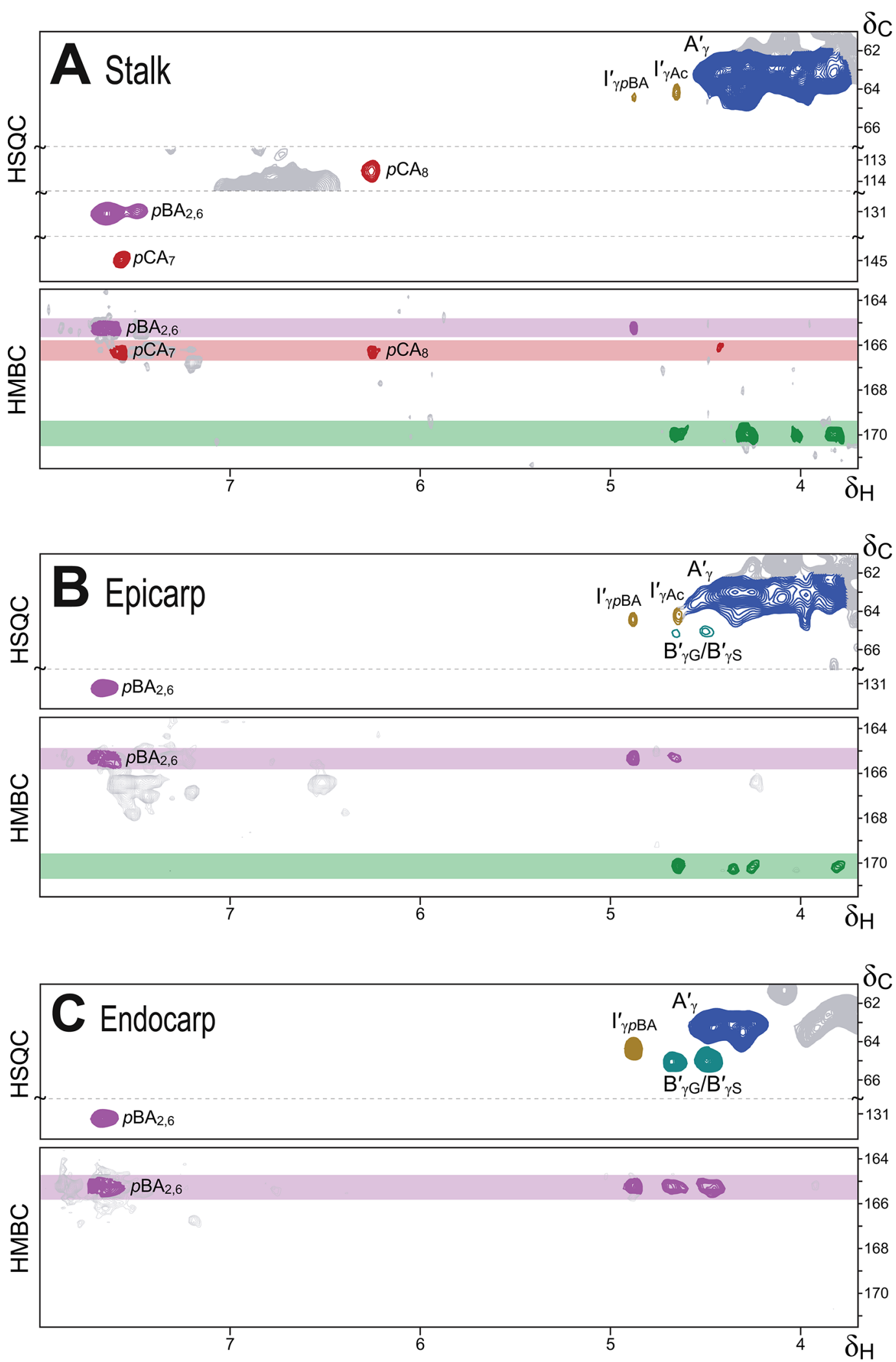

Figure 7. Sections of the HMBC spectra $\left(\delta_{\mathrm{C}} / \delta_{\mathrm{H}} 164-171 / 3.7-8.0\right)$ of the MWLs isolated from (A) stalk, (B) epicarp, and (C) endocarp, showing the main correlations for the carbonyl carbons of the different groups acylating the $\gamma$-OH of the lignin side-chains. Three distinct carbonyl carbons correlations could be observed at $\delta_{\mathrm{C}} 165.1$ for $p$-hydroxybenzoates $p \mathrm{BA}$, at $\delta_{\mathrm{C}} 166.0$ for $p$-coumarates $p \mathrm{CA}$, and at $\delta_{\mathrm{C}} 169.9$ for acetates Ac. Appropriate sections of the HSQC spectra showing the $\mathrm{C}_{\gamma} / \mathrm{H}_{\gamma}$ correlations of the acylated lignin $\left(\delta_{\mathrm{C}} 61-67\right)$ are also depicted.

coupling of two $\gamma$-acylated sinapyl alcohols, were also observed in the spectra. The occurrence of these signals indicate that all these lignins are partially acylated at the $\gamma-\mathrm{OH}$ of the side- chain, most probably with the $p$-hydroxybenzoates observed in the aromatic region, as usually occurs in the lignins from other palms, ${ }^{5,12}$ but also putatively with other acyl groups such as $p$ - 

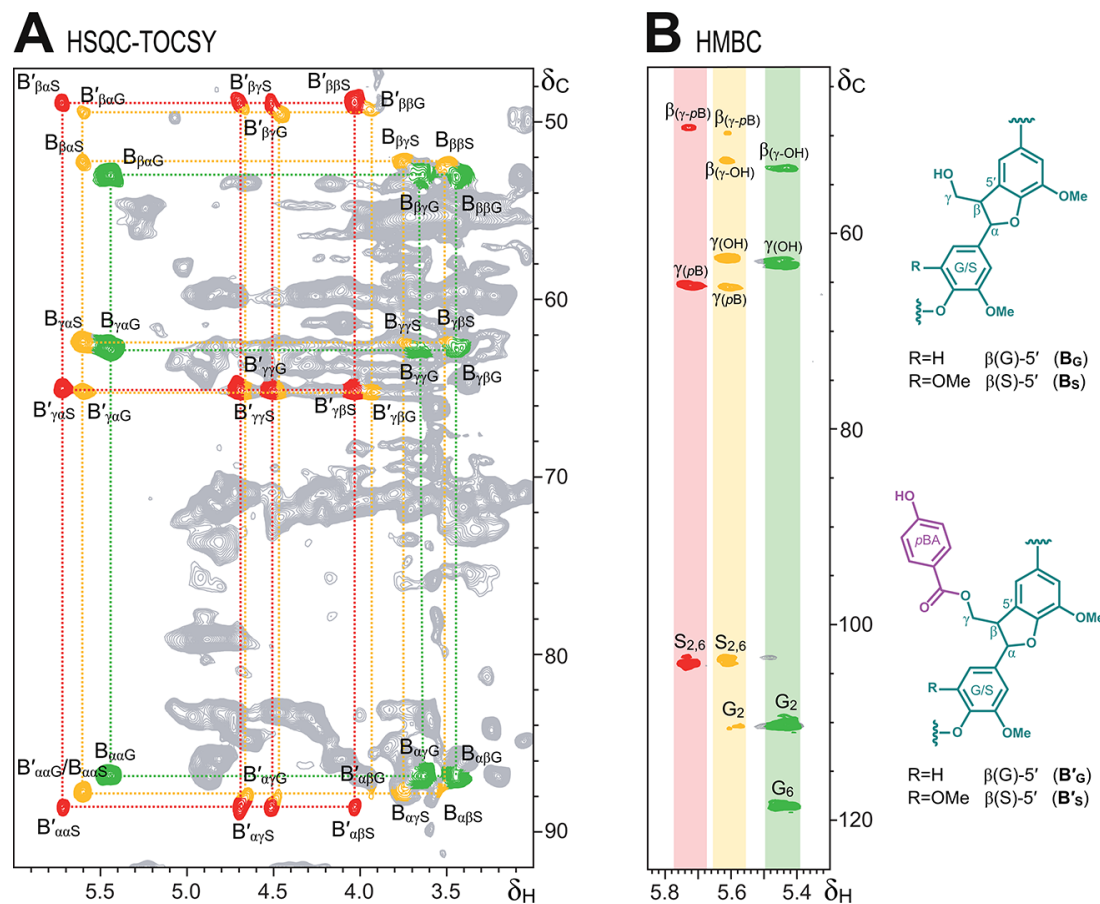

Figure 8. (A) Partial short-range ${ }^{1} \mathrm{H} /{ }^{13} \mathrm{C}$ total correlation (HSQC-TOCSY) spectrum of the lignin from macaúba fruit endocarp showing the main correlations for the $\gamma-\mathrm{OH}$ and $\gamma$ - $p$-hydroxybenzoylated phenylcoumaran structures $\left(\mathbf{B}_{\mathrm{G}}, \mathbf{B}_{\mathrm{S}}, \mathbf{B}_{\mathrm{G}}{ }_{\mathrm{G}}\right.$, and $\left.\mathbf{B}_{\mathrm{S}}{ }_{\mathrm{S}}\right)$. (B) Partial long-range $(\mathrm{HMBC}){ }^{1} \mathrm{H} /{ }^{13} \mathrm{C}$ spectra of the lignin from macaúba fruit endocarp showing the main correlations for the $\alpha$-proton of the different $\gamma$-OH and $\gamma$-phydroxybenzoylated phenylcoumaran structures $\left(\mathbf{B}_{\mathrm{G}}, \mathbf{B}_{\mathrm{S}}, \mathbf{B}_{\mathrm{G}}{ }_{\mathrm{G}}\right.$, and $\left.\mathbf{B}_{\mathrm{S}}{ }_{\mathrm{S}}\right)$. The structures for the different phenylcoumaran are also shown.

coumarates, that are also observed in the aromatic regions of the spectra, and acetates. Partial acylation with acetates was evident in the HSQC of the stalks MWL from the signal of $\gamma$ acetylated cinnamyl alcohol groups $\mathrm{I}^{\prime}{ }_{\gamma \mathrm{Ac}}$ at $\delta_{\mathrm{C}} / \delta_{\mathrm{H}} 64.0 / 4.65$, which is different from the signal for the $\gamma$-p-hydroxybenzoylated cinnamyl alcohol end-groups $\mathbf{I}_{\gamma p \mathrm{BA}}^{\prime}$ at $\delta_{\mathrm{C}} / \delta_{\mathrm{H}} 64.4 / 4.88$. Monolignol conjugates with different acyl groups (acetates, $p$ coumarates, and $p$-hydroxybenzoates) have been widely found in the lignins of many plants, including palms. ${ }^{7-12,44,45}$ An estimation of the extent of $\gamma$-acylation of these lignins was obtained by integration of the $\mathrm{C}_{\gamma} / \mathrm{H}_{\gamma}$ correlation signals corresponding to the nonacylated $\gamma$-OH $\left(\mathbf{A}_{\gamma}\right)$ and $\gamma$-acylated $\left(\mathbf{A}_{\gamma}^{\prime}\right)$ substructures in the spectra of the isolated MWLs and ranged from $26 \%$ in the stalks to only $9 \%$ in the epicarp and $18 \%$ in endocarp.

Additional information about the nature of the ester groups here was obtained from $\mathrm{HMBC}$ experiments. Figure 7 shows the sections of the HMBC spectra for the correlations of the carbonyl carbons of the different esters present in the lignins of the three macaúba parts; appropriate sections of the HSQC spectra showing the signals of the $\gamma$-acylated side-chain regions are also shown. Three distinct carbonyl carbon correlations could be observed in the HMBC spectra, at $\delta_{\mathrm{C}} 165.1$ (magenta highlighting, for $p$-hydroxybenzoates $p \mathbf{B A}$ ), $\delta_{\mathrm{C}} 166.1$ (red, for $p$-coumarates $p \mathrm{CA}$ ), and $\delta_{\mathrm{C}} 169.9$ (green, for acetates Ac). The correlations of the carbonyl carbon at $\delta_{\mathrm{C}} 165.1$ with the 2- and 6-protons at $\delta_{\mathrm{H}} 7.66$ confirmed that they belong to $p$ hydroxybenzoates; likewise, the correlations of the carbonyl carbon at $\delta_{\mathrm{C}} 166.1$ with the 7 and 8 -protons from $p$ coumarates at $\delta_{\mathrm{H}} 7.58$ and 6.26 also confirmed that they belong to $p$-coumarates $p$ CA. Finally, the correlations of the carbonyl carbon at $\delta_{\mathrm{C}} 169.9$ with the methyl group protons of acetates at $\delta_{\mathrm{H}}$ 1.9-2.0 (not shown) also confirmed its assignment. The correlations of all these carbonyl carbons with the protons in the range $\delta_{\mathrm{H}} \approx 3.6-5.0 \mathrm{ppm}$ indicate that all of them are acylating the $\gamma-\mathrm{OH}$ of the lignin side-chain. Several correlations were observed in this region suggesting the involvement of the different acyl groups at the $\gamma$-positions of different lignin substructures $\left(\mathbf{A}^{\prime}, \mathbf{B}^{\prime}\right.$, and $\left.\mathbf{I}^{\prime}\right)$. The main acylating groups found in the lignin of the stalks were $p$ hydroxybenzoates $p \mathbf{B A}, p$-coumarates $p \mathbf{C A}$, and acetates, whereas in the epicarp lignin, the main acylating groups were $p$-hydroxybenzoates $\mathbf{p} \mathbf{B A}$ and acetates. In the endocarp lignin, $p$-hydroxybenzoate $\boldsymbol{p} \mathbf{B A}$ was the only group acylating the lignin $\gamma-\mathrm{OH}$.

The HSQC spectrum of the endocarp MWL (Figure 4C) also shows the occurrence of strong signals for $\gamma$-acylated (with $p$-hydroxybenzoates) phenylcoumaran structures $\mathbf{B}^{\prime}$, which are described and assigned here for the first time. The spectrum shows the presence of three separate and distinguishable signals for the $\mathrm{C}_{\alpha} / \mathrm{H}_{\alpha}$ correlations of phenylcoumaran structures (labeled here $\mathbf{B}_{\mathrm{G}}, \mathbf{B}_{\mathrm{S}} / \mathbf{B}^{\prime}{ }_{\mathrm{G}}$, and $\mathbf{B}_{\mathrm{S}}{ }_{\mathrm{S}}$ ). Although signal $\mathbf{B}_{\mathrm{G}}$ can be clearly assigned to $\mathrm{C}_{\alpha} / \mathrm{H}_{\alpha}$ correlations of a $\mathbf{G}-\mathbf{G}$ phenylcoumaran unit, the two other signals have not been reported previously in the $2 \mathrm{D}$ NMR of other lignins. Important information regarding these signals was obtained from the HSQC-TOCSY and HMBC spectra (Figure 8). It is clear from the HSQC-TOCSY spectrum (Figure $8 \mathrm{~A}$ ) that signal $\mathbf{B}_{\mathrm{G}}$ presents a three-carbon side-chain and corresponds to the typical signal from $\mathbf{G}-\mathbf{G}$ phenylcoumaran structures, with the characteristic $\mathrm{C}_{\alpha} / \mathrm{H}_{\alpha}, \mathrm{C}_{\beta} / \mathrm{H}_{\beta}$, and $\mathrm{C}_{\gamma} / \mathrm{H}_{\gamma}$ correlations at $\delta_{\mathrm{C}} / \delta_{\mathrm{H}}$ $86.8 / 5.43$, 53.1/3.45, and 62.7/3.68. Similarly, signal $\mathbf{B}^{\prime}{ }_{S}$ presents a three-carbon side-chain coupled methine network, with its $\mathrm{C}_{\alpha} / \mathrm{H}_{\alpha}$ and $\mathrm{C}_{\beta} / \mathrm{H}_{\beta}$ correlations at $\delta_{\mathrm{C}} / \delta_{\mathrm{H}} 88.6 / 5.71$ and 49.0/4.02 and a signal pair for the $\mathrm{C}_{\gamma} / \mathrm{H}_{\gamma}$ correlations at $\delta_{\mathrm{C}} / \delta_{\mathrm{H}}$ $65.1 /(4.67$ and 4.50$)$ that corresponds to phenylcoumaran structures bearing a $p$-hydroxybenzoate group acylating the $\gamma$ $\mathrm{OH}$, as can be clearly seen from the HMBC correlations of the 
carbonyl carbon at $\delta_{\mathrm{C}} 165.1$ in Figure 7. However, the HSQCTOCSY of Figure 8A clearly indicates that the signal labeled $\mathbf{B}^{\prime}{ }_{\mathrm{G}} / \mathbf{B}_{\mathrm{S}}$ is composed of two overlapped signals that correspond to two different phenylcoumaran structures: structures $\mathbf{B}_{\mathrm{S}}$ with a normal $\gamma-\mathrm{OH}$, and structures $\mathbf{B}^{\prime}{ }_{\mathrm{G}}$ in which the $\gamma-\mathrm{OH}$ is acylated with $p$-hydroxybenzoates. The final assignments of these signals were obtained from the long-range correlations in the $\mathrm{HMBC}$ spectrum (Figure $8 \mathrm{~B}$ ). The $\alpha$-proton of $\mathbf{B}_{\mathrm{G}}$ units correlates only with $\mathbf{G}$-unit aromatic carbons $\left(\mathbf{G}_{2}\right.$ and $\left.\mathbf{G}_{6}\right)$ and the $\gamma$-carbon of a free $\gamma$-OH side chain, indicating that it corresponds to normal $\mathbf{G}-\mathbf{G}$ phenylcoumaran structures. The $\alpha$-proton of $\mathbf{B}^{\prime}{ }_{\mathrm{S}}$ only correlates with $\mathbf{S}$-unit aromatic carbons $\left(\mathbf{S}_{2,6}\right)$ and the $\gamma$-carbon of a $\gamma$-O-p-hydroxybenzoylated side chain, indicating that it corresponds to $\mathbf{S}-\mathbf{G}$ phenylcoumaran structures bearing a $p$-hydroxybenzoate unit acylating the $\gamma$ $\mathrm{OH}$. Finally, signal $\mathbf{B}_{\mathrm{S}}$ corresponds to an $\mathbf{S}-\mathbf{G}$ phenylcoumaran bearing a normal $\gamma-\mathrm{OH}$ whereas signal $\mathbf{B}^{\prime}{ }_{\mathrm{G}}$ corresponds to a G-G phenylcoumaran bearing a $p$-hydroxybenzoate group at the $\gamma$-OH.

Quantitation of Lignin Units and Linkages. The relative abundances of the $\mathbf{H}, \mathbf{G}$, and $\mathbf{S}$ lignin units, $p$-hydroxybenzoates $p \mathbf{B A}, p$-hydroxycinnamates ( $p \mathbf{C A}$ and FA), and piceatannol $\mathbf{P}$ units, as well as the main interunit linkages, cinnamyl end-groups, and the percentage of $\gamma$-OH acylation, calculated from volume integrals from the HSQC spectra of the whole cell-walls and of their respective MWLs, are shown in Table 3. Important information regarding the structure of the lignins in the different macaúba parts could be obtained. The lignin from stalks was slightly enriched in S-lignin units $(\mathbf{S} / \mathbf{G}$ ratio $\sim 1.2)$ and $\beta$-ethers $\mathbf{A}$, with a high extent of $\gamma$ acylation (26\% lignin acylation), predominantly with $p$ hydroxybenzoates, and also with $p$-coumarates and acetates. The epicarp lignin, on the other hand, was highly enriched in G-lignin units (S/G ratio of 0.2$)$ and was depleted in $\beta$-ethers A, but consequently presented more condensed linkages such as phenylcoumarans $\mathbf{B} / \mathbf{B}^{\prime}$ and dibenzodioxocins $\mathbf{D}$. It also shows a low extent of $\gamma$-acylation ( $9 \%$ lignin acylation) with $p$ hydroxybenzoates and acetates. Finally, the endocarp lignin, with an S/G of $0.6-0.9$, presented a completely different structure extremely enriched in condensed linkages (phenylcoumarans $\mathbf{B} / \mathbf{B}^{\prime}$, dibenzodioxocins $\mathbf{D}$ ) and depleted in $\beta-$ ethers, with important amounts of $p$-hydroxybenzoates $p \mathbf{B A}$ acylating the $\gamma-\mathrm{OH}$, and, most strikingly, with large amounts of piceatannol units integrally incorporated into the lignin polymer (forming phenylcoumaran $\mathbf{P}_{\mathfrak{c}}$ and benzodioxane $\mathbf{P}_{b}$ and $\mathbf{V}$ structures). Interestingly, no traces of the flavonoid tricin could be detected in any of these lignins, despite prior observations that tricin is a characteristic component in the lignins of monocots, ${ }^{15,17}$ and has been found in the lignins of other palms, such as in coconut fibers. ${ }^{11}$

Nature of Lignin $\gamma$-Acylation as Determined by DFRC. Further information on the nature of the $\gamma$-acylation was obtained by DFRC, a degradation method that cleaves $\beta$-ether bonds in the lignin but leaves $\gamma$-esters intact. ${ }^{33}$ Large differences were observed among the DFRC degradation products of the MWLs isolated from the different macaúba parts (Figure 9). All lignins releases the cis and trans isomers of guaiacyl ( $c \mathbf{G}$ and $t \mathbf{G}$ ), and syringyl ( $c \mathbf{S}$ and $t \mathbf{S}$ ) lignin monomers (as their acetylated derivatives) arising from normal $(\gamma-\mathrm{OH})$ units in lignin. The presence of important peaks corresponding to the cis and trans isomers of $\gamma-p$ hydroxybenzoylated syringyl $\left(c \mathrm{~S}_{p \mathrm{BA}}\right.$ and $\left.t \mathrm{~S}_{p \mathrm{BA}}\right)$ lignin units in the DFRC chromatograms of the stalks and the endocarp
Table 3. Structural Characteristics (Lignin Inter-Unit Linkage Types, End-Groups, $\gamma$-Acylation, Aromatic Units, and S/G Ratio, $p$-Hydroxybenzoate and $p$ -

Hydroxycinnamate Contents) from Volume Integration of ${ }^{1} \mathrm{H} /{ }^{13} \mathrm{C}$ Correlation Signals in the HSQC Spectra of the MWLs Isolated from the Different Macaúba Parts

\begin{tabular}{|c|c|c|c|c|c|c|}
\hline & \multicolumn{2}{|c|}{ stalk } & \multicolumn{2}{|c|}{ fruit epicarp } & \multicolumn{2}{|c|}{$\begin{array}{c}\text { fruit } \\
\text { endocarp }\end{array}$} \\
\hline & $\mathrm{CW}$ & MWL & $\mathrm{CW}$ & MWL & $\mathrm{CW}$ & MWL \\
\hline \multicolumn{7}{|c|}{ Lignin Interunit Linkages (\%) } \\
\hline$\beta-O-4^{\prime}$ aryl ethers $\left(\mathbf{A} / \mathbf{A}^{\prime}\right)$ & & 84 & & 65 & & 64 \\
\hline phenylcoumarans $\left(\mathbf{B} / \mathbf{B}^{\prime}\right)$ & & 9 & & 24 & & 18 \\
\hline resinols $(\mathbf{C})$ & & 3 & & 4 & & 3 \\
\hline tetrahydrofurans $\left(\mathbf{C}^{\prime}\right)$ & & 1 & & 0 & & 1 \\
\hline dibenzodioxocins (D) & & 0 & & 3 & & 1 \\
\hline spirodienones (F) & & 3 & & 4 & & 3 \\
\hline benzodioxanes $(\mathbf{V})$ & & 0 & & 0 & & 1 \\
\hline benzodioxanes $\left(\mathbf{P}_{\mathbf{b}}\right)$ & & 0 & & 0 & & 4 \\
\hline phenylcoumarans (Pc) & & 0 & & 0 & & 5 \\
\hline \multicolumn{7}{|c|}{ Lignin End-Groups $^{a}$} \\
\hline $\begin{array}{l}\text { cinnamyl alcohol end-groups } \\
\text { (I) }\end{array}$ & & 3 & & 5 & & 5 \\
\hline $\begin{array}{l}\gamma \text {-acylated cinnamyl alcohol } \\
\text { end-groups }\left(\mathbf{I}^{\prime}\right)\end{array}$ & & 1 & & 0 & & 3 \\
\hline $\begin{array}{l}\text { cinnamaldehyde end-groups } \\
(\mathrm{J})\end{array}$ & & 4 & & 6 & & 9 \\
\hline$\underset{(\%)}{\text { lignin side-chain } \gamma \text {-acylation }}$ & & 26 & & 9 & & 18 \\
\hline \multicolumn{7}{|c|}{ Lignin Aromatic Units (\%) } \\
\hline $\mathbf{H}(\%)$ & 2 & 1 & 6 & 1 & 1 & 1 \\
\hline G (\%) & 45 & 46 & 80 & 84 & 51 & 62 \\
\hline $\mathbf{S}(\%)$ & 53 & 53 & 14 & 15 & 48 & 37 \\
\hline$S / G$ ratio & 1.2 & 1.2 & 0.2 & 0.2 & 0.9 & 0.6 \\
\hline \multicolumn{7}{|c|}{$p$-Hydroxycinnamates ${ }^{b}$} \\
\hline$p$-coumarates $p$ CA $(\%)$ & 2 & 2 & 0 & 0 & 0 & 0 \\
\hline ferulates FA (\%) & 3 & 2 & 2 & 3 & 0 & 0 \\
\hline$\underset{(\%)}{p \text {-hydroxybenzoates }{ }^{b} p \mathbf{B A}}$ & 26 & 16 & 9 & 4 & 50 & 40 \\
\hline piceatannol units ${ }^{b} \mathbf{P}(\%)$ & 0 & 0 & 0 & 0 & 50 & 10 \\
\hline \multicolumn{7}{|c|}{$\begin{array}{l}{ }^{a} \text { Expressed as a fraction of the total lignin interunit linkage types } A- \\
\text { F. }{ }^{b} p \text {-Coumarate, ferulate and piceatannol contents as percentages of } \\
\text { lignin content }(\mathbf{H}+\mathbf{G}+\mathbf{S}=100) \text {. }\end{array}$} \\
\hline
\end{tabular}

indicated the occurrence of significant amounts of $p$ hydroxybenzoate groups acylating the $\gamma-\mathrm{OH}$ of these lignins, and predominantly on syringyl units, as usually occurs in the lignins from palms. ${ }^{11,12}$ Only minor amounts of $t \boldsymbol{S}_{p \mathrm{BA}}$ were found in the lignin from epicarp, in agreement with the low amounts of $p$-hydroxybenzoates and the low level of $\gamma$ acylation observed in this lignin by 2D-NMR. A minor peak for the trans- $\gamma$-dihydro- $p$-coumaroylated syringyl $\left(t \mathrm{~S}_{p \mathrm{DHCA}}\right)$ lignin units was detected in the lignin from the stalks, indicating that the $p$-coumarates are also attached to the $\gamma-\mathrm{OH}$ of these lignins, as observed by $2 \mathrm{D}-\mathrm{NMR}$, and predominantly on syringyl units. Interestingly, significant amounts of cis and trans isomers of $\gamma$-benzoylated guaiacyl $\left(c \mathrm{G}_{\mathrm{BA}}\right.$ and $\left.t \mathrm{G}_{\mathrm{BA}}\right)$ and syringyl $\left(c S_{\mathrm{BA}}\right.$ and $\left.t \mathrm{~S}_{\mathrm{BA}}\right)$ lignin units could also be released among the DFRC products of endocarp (Figure 9C) and at lower levels also in the stalks (Figure 9A). These monolignol benzoate conjugates have also been recently described in other palms. ${ }^{44}$ However, and contrary to what occurs with $p$ hydroxybenzoates $p \mathbf{B A}$ and $p$-coumarates $p \mathbf{C A}$ that are mostly attached to $\mathbf{S}$-lignin units, the benzoates $\mathbf{B A}$ found in these 

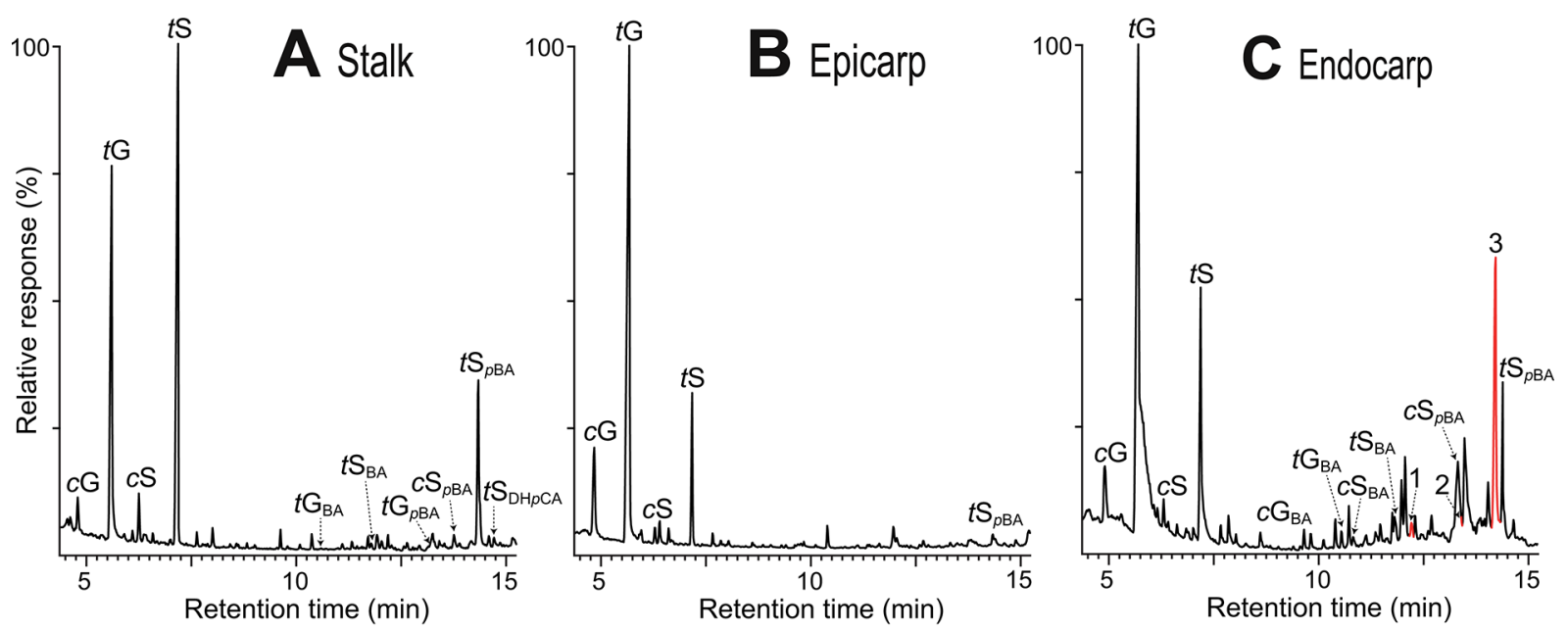

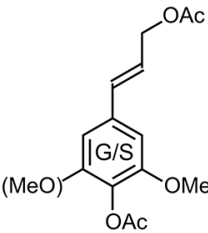

$\mathrm{G} / \mathrm{S}$

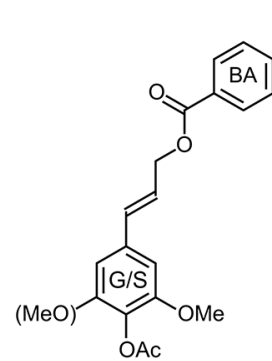

$\mathrm{G}_{\mathrm{BA}} / \mathrm{S}_{\mathrm{BA}}$
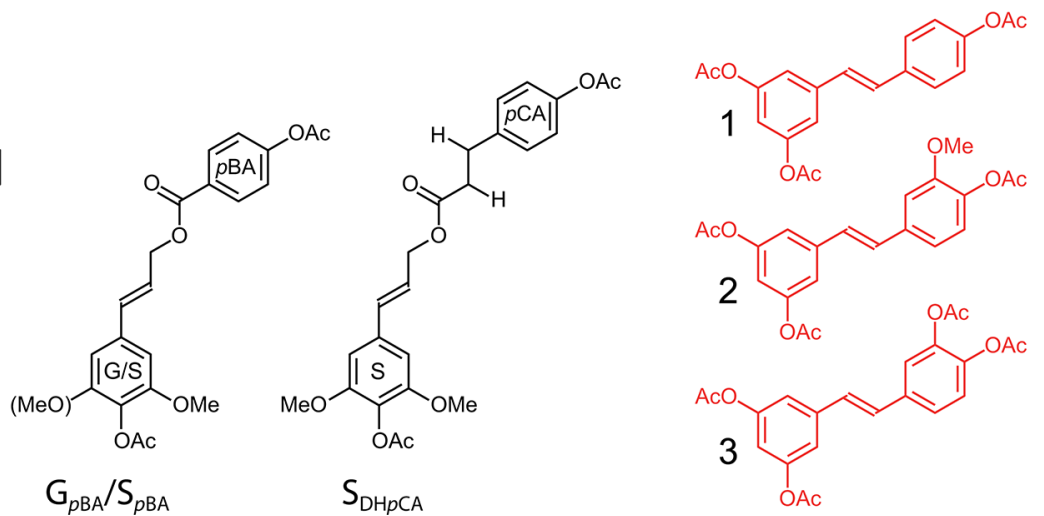

Figure 9. Chromatograms of the DFRC degradation products released from the lignins from (A) macaúba stalk, (B) macaúba fruit epicarp, and (C) macaúba fruit endocarp. $c \mathbf{G}, t \mathbf{G}, c \mathbf{S}$, and $t \mathbf{S}$ are the normal cis- and trans-coniferyl $(\mathbf{G})$ and sinapyl (S) alcohol monomers (as their acetate derivatives). $c \mathbf{G}_{\mathrm{BA}}$ and $t \mathbf{G}_{\mathrm{BA}}$ are the cis- and trans-coniferyl benzoate $\left(\mathbf{G}_{\mathrm{BA}}\right) ; c \mathrm{~S}_{\mathrm{BA}}$ and $t \mathrm{~S}_{\mathrm{BA}}$ are the cis- and trans-sinapyl benzoate $\left(\mathbf{S}_{\mathrm{BA}}\right)$; $t \mathrm{G}_{p \mathrm{BA}}$ is the trans-coniferyl $p$-hydroxybenzoate $\left(\mathrm{G}_{p \mathrm{BA}}\right) ; c \mathrm{~S}_{p \mathrm{BA}}$ and $t \mathrm{~S}_{p \mathrm{BA}}$ are the cis- and trans-sinapyl $p$-hydroxybenzoates $\left(\mathrm{S}_{p \mathrm{BA}}\right) ; t \mathrm{~S}_{\mathrm{DH} p \mathrm{CA}}$ is the trans-sinapyl dihydro- $p$-coumarate $\left(\mathbf{S}_{\mathrm{DH} p \mathrm{CA}}\right)$, (as their acetyl derivatives). Peaks in red color correspond to the different hydroxystilbene compounds, $\mathbf{1}$ : resveratrol; 2: isorhapontigenin; 3: piceatannol, as their acetyl derivatives.

lignins do not have a preference for $\mathbf{G}$ - or $\mathbf{S}$-units and are present in a similar proportion as the lignin $\mathbf{S} / \mathbf{G}$ ratio. Significant amounts of the stilbene piceatannol 3, were released upon DFRC from the endocarp lignin. Two other related stilbenes, namely resveratrol $\mathbf{1}$, and isorhapontigenin 2 , were also released, although in lower amounts. This finding indicates that, besides the structures involving piceatannol $\left(\mathbf{P}_{\mathbf{b}}, \mathbf{P}_{c}\right.$, and V) described above, significant amounts of piceatannol are also incorporated into the lignin structure of the endocarp by ethertype labile bonds, susceptible of being cleaved by the DFRC degradation method.

In general terms, the molar $\mathbf{S} / \mathbf{G}$ ratios obtained upon DFRC (1.4 for stalks, 0.2 for epicarp, and 0.3 for endocarp) matches well those obtained by Py-GC/MS and 2D-NMR, except for the endocarp, which is somewhat lower. Probably, in the endocarp lignin, the $\mathbf{S}$-units might be involved in some types of linkages with piceatannol that are not amenable to DFRC degradation.

Acetate groups have also been widely found acylating the $\gamma$ $\mathrm{OH}$ in the lignin of many plants, including palms, ${ }^{7,11}$ and their presence in the lignins of stalks and epicarp were also noticed in the HMBC spectra of Figure 7. Acetate groups can be detected by using a modification of the original DFRC degradation method by substituting acetylating reagents with propionylating ones (so-called DFRC')., ${ }^{74}$ The DFRC' analyses corroborated the occurrence of significant amounts of acetates attached to the $\gamma-\mathrm{OH}$ in the stalks and epicarp lignins, which were preferentially attached to S-lignin units. Up to $33 \%$ of the releasable S-lignin units were acetylated in stalk lignin, whereas only around $4 \%$ of the total G-lignin units were acetylated. In the case of epicarp lignin, the percentages of acetylation were $9 \%$ and $1 \%$ for $\mathbf{S}$ - and G-lignin units, respectively. The endocarp lignin, however, was barely acetylated $(\sim 1 \%$ of $\mathbf{S}$-units and $\sim 0.2 \%$ of G-units were acetylated).

Molecular Weight Distribution of the Lignins from the Different Macaúba Parts. The molecular weightaverage $\left(M_{\mathrm{w}}\right)$ and number-average $\left(M_{\mathrm{n}}\right)$ values of the MWLs isolated from the three different macaúba parts were estimated from the GPC curves, as shown in Figure S1. The MWLs exhibited rather similar molecular weights, with $M_{\mathrm{w}} / M_{\mathrm{n}}$ ranging from $7400 / 4200 \mathrm{~g} / \mathrm{mol}$ in the stalk lignin, 6100/ $3400 \mathrm{~g} / \mathrm{mol}$ in the epicarp lignin, and $6500 / 3900 \mathrm{~g} / \mathrm{mol}$ in the endocarp lignin. The MWLs therefore exhibited relatively low polydispersity, with $M_{\mathrm{w}} / M_{\mathrm{n}}$ around 1.67-1.79, compared to other isolated lignins. ${ }^{48}$

In conclusion, the three anatomical parts (stalk, epicarp, and endocarp) of the macaúba palm presented completely different cell wall compositions, with important differences in the content and composition of lignin. Whereas the stalks were 
enriched in $\mathbf{S}$-lignin units and $\beta$-ethers $\mathbf{A}$, the epicarp presented a highly condensed, $\mathbf{G}$-rich lignin ( $\mathbf{S} / \mathbf{G}$ ratio of 0.2 ). The endocarp, on the other hand, was characterized by the occurrence of significant amounts of hydroxystilbenes, particularly piceatannol, incorporated into the lignin structure, thus producing a greater accumulation of lignin that is more condensed and presumably contributing to endocarp hardening by reinforcing the cell wall. We speculate that incorporation of these hydroxystilbenes, and in particular piceatannol, into the lignin polymer could also provide additional antiviral, antibacterial, and antioxidant properties to the endocarp, contributing to seed protection.

\section{ASSOCIATED CONTENT}

\section{S Supporting Information}

The Supporting Information is available free of charge on the ACS Publications website at DOI: 10.1021/acs.jafc.7b04638.

Supplementary Table S1. Assignments of the ${ }^{1} \mathrm{H} /{ }^{13} \mathrm{C}$ correlation signals in the HSQC spectra (in DMSO- $d_{6}$ ) of the lignins from the different macaúba parts. Supplementary Table S2. Assignments of the carbohydrate ${ }^{1} \mathrm{H} /{ }^{13} \mathrm{C}$ correlation signals in the HSQC spectra of the different macaúba parts. Supplementary Figure S1. Molecular weight distributions of the lignins from stalk, epicarp, and endocarp of macaúba palm fruit. (PDF)

\section{AUTHOR INFORMATION}

\section{Corresponding Author}

*Tel: +34 954624711. Fax: +34 954624002. E-mail: delrio@ irnase.csic.es.

\section{ORCID}

Jorge Rencoret: 0000-0003-2728-7331

Hoon Kim: 0000-0001-7425-7464

Ana Gutiérrez: 0000-0002-8823-9029

John Ralph: 0000-0002-6093-4521

José C. del Río: 0000-0002-3040-6787

\section{Funding}

This study has been funded by the Spanish Projects AGL201453730-R, CTQ2014-60764-JIN, and AGL2017-83036-R (cofinanced by FEDER funds) and the CSIC project 2014-40E097. John Ralph and Hoon Kim were funded by the DOE Great Lakes Bioenergy Research Center (DOE BER Office of Science DE-FC02-07ER64494).

\section{Notes}

The authors declare no competing financial interest.

\section{ACKNOWLEDGMENTS}

The authors are grateful to Dr. Manuel Angulo (General Research Services of the University of Seville, SGI-CITIUS) for technical assistance during the NMR analyses.

\section{REFERENCES}

(1) Evaristo, A. B.; Grossi, J. A. S.; Carneiro, A. d. C. O.; Pimentel, L. D.; Motoike, S. Y.; Kuki, K. N. Actual and putative potentials of macauba palm as feedstock for solid biofuel production from residues. Biomass Bioenergy 2016, 85, 18-24.

(2) Motoike, S. Y.; Kuki, K. N. The potential of macaw palm (Acrocomia aculeata) as source of biodiesel in Brazil. Int. Rev. Chem. Eng. Commun. 2009, 1, 632-635.

(3) del Río, J. C.; Evaristo, A. B.; Marques, G.; Martín-Ramos, P.; Martín-Gil, J.; Gutiérrez, A. Chemical composition and thermal behavior of the pulp and kernel oils from macauba palm (Acrocomia aculeata) fruit. Ind. Crops Prod. 2016, 84, 294-304.

(4) Reis, S. B.; Mercadante-Simões, M. O.; Ribeiro, L. M. Pericarp development in the macaw palm Acrocomia aculeata (Arecaceae). Rodriguésia 2012, 63, 541-549.

(5) del Río, J. C.; Rencoret, J.; Gutiérrez, A.; Kim, H.; Ralph, J. Hydroxystilbenes are monomers in palm fruit endocarp lignins. Plant Physiol. 2017, 174, 2072-2082.

(6) Vanholme, R.; Morreel, K.; Ralph, J.; Boerjan, W. Lignin biosynthesis and structure. Plant Physiol. 2010, 153, 895-905.

(7) del Río, J. C.; Marques, G.; Rencoret, J.; Martínez, A. T.; Gutiérrez, A. Occurrence of naturally acetylated lignin units. J. Agric. Food Chem. 2007, 55, 5461-5468.

(8) del Río, J. C.; Rencoret, J.; Marques, G.; Gutiérrez, A.; Ibarra, D.; Santos, J. I.; Jiménez-Barbero, J.; Zhang, L. M.; Martínez, A. T. Highly acylated (acetylated and/or $p$-coumaroylated) native lignins from diverse herbaceous plants. J. Agric. Food Chem. 2008, 56, 9525-9534.

(9) Ralph, J. Hydroxycinnamates in lignification. Phytochem. Rev. 2010, 9, 65-83.

(10) Karlen, S. D.; Zhang, C.; Peck, M. L.; Smith, R. A.; Padmakshan, D.; Helmich, K. E.; Free, H. C. A.; Lee, S.; Smith, B. G.; Lu, F.; Sedbrook, J. C.; Sibout, R.; Grabber, J. H.; Runge, T. M.; Mysore, K. S.; Harris, P. J.; Bartley, L. E.; Ralph, J. Monolignol ferulate conjugates are naturally incorporated into plant lignins. Sci. Adv. 2016, 2, e1600393.

(11) Rencoret, J.; Ralph, J.; Marques, G.; Gutiérrez, A.; Martínez, Á. T.; del Río, J. C. Structural characterization of lignin isolated from coconut (Cocos nucifera) coir fibers. J. Agric. Food Chem. 2013, 61, 2434-2445.

(12) Lu, F.; Karlen, S.; Regner, M.; Kim, H.; Ralph, S.; Sun, R.-C.; Kuroda, K.-i.; Augustin, M.; Mawson, R.; Sabarez, H.; Singh, T.; Jimenez-Monteon, G.; Zakaria, S.; Hill, S.; Harris, P.; Boerjan, W.; Wilkerson, C.; Mansfield, S.; Ralph, J. Naturally $p$-hydroxybenzoylated lignins in palms. BioEnergy Res. 2015, 8, 934-952.

(13) Chen, F.; Tobimatsu, Y.; Havkin-Frenkel, D.; Dixon, R. A.; Ralph, J. A polymer of caffeyl alcohol in plant seeds. Proc. Natl. Acad. Sci. U. S. A. 2012, 109, 1772-1777.

(14) Chen, F.; Tobimatsu, Y.; Jackson, L.; Nakashima, J.; Ralph, J.; Dixon, R. A. Novel seed coat lignins in the Cactaceae: structure, distribution and implications for the evolution of lignin diversity. Plant J. 2013, 73, 201-211.

(15) del Río, J. C.; Rencoret, J.; Prinsen, P.; Martínez, Á. T.; Ralph, J.; Gutiérrez, A. Structural characterization of wheat straw lignin as revealed by analytical pyrolysis, $2 \mathrm{D}-\mathrm{NMR}$, and reductive cleavage methods. J. Agric. Food Chem. 2012, 60, 5922-5935.

(16) del Río, J. C.; Lino, A. G.; Colodette, J. L.; Lima, C. F.; Gutiérrez, A.; Martínez, Á. T.; Lu, F.; Ralph, J.; Rencoret, J. Differences in the chemical structure of the lignins from sugarcane bagasse and straw. Biomass Bioenergy 2015, 81, 322-338.

(17) Lan, W.; Lu, F.; Regner, M.; Zhu, Y.; Rencoret, J.; Ralph, S. A.; Zakai, U. I.; Morreel, K.; Boerjan, W.; Ralph, J. Tricin, a flavonoid monomer in monocot lignification. Plant Physiol. 2015, 167, 12841295.

(18) Lan, W.; Morreel, K.; Lu, F.; Rencoret, J.; del Río, J. C.; Voorend, W.; Vermerris, W.; Boerjan, W.; Ralph, J. Maize tricinoligolignol metabolites and their implications for monocot lignification. Plant Physiol. 2016, 171, 810-820.

(19) Lan, W.; Rencoret, J.; Lu, F.; Karlen, S. D.; Smith, B. G.; Harris, P. J.; del Río, J. C.; Ralph, J. Tricin-lignins: occurrence and quantitation of tricin in relation to phylogeny. Plant J. 2016, 88, $1046-1057$.

(20) Boudet, A. M. Lignins and lignification: Selected issues. Plant Physiol. Biochem. 2000, 38, 81-96.

(21) Campbell, M.; Sederoff, R. R. Variation in lignin content and composition. Plant Physiol. 1996, 110, 3-13.

(22) Donaldson, L. A. Lignification and lignin topochemistry - an ultrastructural view. Phytochemistry 2001, 57, 859-873.

(23) Lourenço, A.; Rencoret, J.; Chemetova, C.; Gominho, J.; Gutiérrez, A.; del Río, J. C.; Pereira, H. Lignin composition and 
structure differs between xylem, phloem and phellem in Quercus suber L. Front. Plant Sci. 2016, 7, 1612.

(24) Rencoret, J.; Gutiérrez, A.; Nieto, L.; Jiménez-Barbero, J.; Faulds, C. B.; Kim, H.; Ralph, J.; Martínez, Á. T.; del Río, J. C. Lignin composition and structure in young versus adult Eucalyptus globulus plants. Plant Physiol. 2011, 155, 667-682.

(25) Barros, J.; Serk, H.; Granlund, I.; Pesquet, E. The cell biology of lignification in higher plants. Ann. Bot. (Oxford, U. K.) 2015, 115, 1053-1074.

(26) Schuetz, M.; Smith, R.; Ellis, B. Xylem tissue specification, patterning, and differentiation mechanisms. J. Exp. Bot. 2013, 64, 1131.

(27) Chabannes, M.; Ruel, K.; Yoshinaga, A.; Chabbert, B.; Jauneau, A.; Joseleau, J. P.; Boudet, A. M. In situ analysis of lignins in transgenic tobacco reveals a differential impact of individual transformations on the spatial patterns of lignin deposition at the cellular and subcellular levels. Plant J. 2001, 28, 271-282.

(28) Joseleau, J. P.; Ruel, K. Study of lignification by noninvasive techniques in growing maize internodes - An investigation by Fourier transform infrared cross-polarization magic angle spinning ${ }^{13} \mathrm{C}$-nuclear magnetic resonance spectroscopy and immunocytochemical transmission electron microscopy. Plant Physiol. 1997, 114, 1123-1133.

(29) Terashima, N.; Fukushima, K.; He, L.; Takabe, K. Comprehensive model of the lignified plant cell wall. In Forage Cell Wall Structure and Digestibility; Jung, H. G., Buxton, D. R., Hatfield, R. D., Ralph, J., Eds.; American Society of Agronomy, Crop Science Society of America, Soil Science Society of America: Madison, WI, 1993; pp 247-270.

(30) Tappi Tappi Test Methods 2004-2005; Tappi Press: Norcoss, GA, 2004.

(31) del Río, J. C.; Prinsen, P.; Rencoret, J.; Nieto, L.; JiménezBarbero, J.; Ralph, J.; Martínez, Á. T.; Gutiérrez, A. Structural characterization of the lignin in the cortex and pith of elephant grass (Pennisetum purpureum) stems. J. Agric. Food Chem. 2012, 60, 36193634.

(32) Ralph, J.; Hatfield, R. D. Pyrolysis-GC-MS characterization of forage materials. J. Agric. Food Chem. 1991, 39, 1426-1437.

(33) Lu, F.; Ralph, J. Derivatization followed by reductive cleavage (DFRC method), a new method for lignin analysis: protocol for analysis of DFRC monomers. J. Agric. Food Chem. 1997, 45, 25902592.

(34) Ralph, J.; Lu, F. The DFRC method for lignin analysis. 6. A simple modification for identifying natural acetates on lignins. J. Agric. Food Chem. 1998, 46, 4616-4619.

(35) Kim, H.; Ralph, J.; Akiyama, T. Solution-state 2D NMR of ballmilled plant cell wall gels in DMSO- $d_{6}$. BioEnergy Res. 2008, 1, 56-66.

(36) Rencoret, J.; Marques, G.; Gutiérrez, A.; Nieto, L.; Santos, J. I.; Jiménez-Barbero, J.; Martínez, A. T.; del Río, J. C. HSQC-NMR analysis of lignin in woody (Eucalyptus globulus and Picea abies) and non-woody (Agave sisalana) ball-milled plant materials at the gel state. Holzforschung 2009, 63, 691-698.

(37) Kim, H.; Ralph, J. Solution-state 2D NMR of ball-milled plant

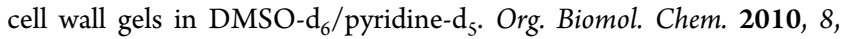
576-591.

(38) Ralph, S. A.; Landucci, L. L.; Ralph, J. NMR database of lignin and cell wall model compounds, 2009. Available at https://www.glbrc. org/databases_and_software/nmrdatabase. (Accessed: 2 November 2011).

(39) Shibata, M.; Varman, M.; Tono, Y.; Miyafuji, H.; Saka, S. Characterization in chemical composition of the oil palm (Elaeis guineensis). J. Japan Inst. Energy 2008, 87, 383-388.

(40) del Río, J. C.; Martín, F.; González-Vila, F. J. Thermally assisted hydrolysis and alkylation as a novel pyrolytic approach for the structural characterization of natural biopolymers and geomacromolecules. TrAC, Trends Anal. Chem. 1996, 15, 70-79.

(41) Kuroda, K.-i.; Ozawa, T.; Ueno, T. Characterization of sago palm (Metroxylon sagu Rottb.) lignin by analytical pyrolysis. J. Agric. Food Chem. 2001, 49, 1840-1847.
(42) Bunzel, M.; Ralph, J.; Kim, H.; Lu, F.; Ralph, S. A.; Marita, J. M.; Hatfield, R. D.; Steinhart, H. Sinapate dehydrodimers and sinapate-ferulate heterodimers in cereal dietary fiber. J. Agric. Food Chem. 2003, 51, 1427-1434.

(43) Ralph, J.; Hatfield, R. D.; Quideau, S.; Helm, R. F.; Grabber, J. H.; Jung, H.-J. G. Pathway of $p$-coumaric acid incorporation into maize lignin as revealed by NMR. J. Am. Chem. Soc. 1994, 116, 94489456.

(44) Karlen, S. D.; Smith, R. A.; Kim, H.; Padmakshan, D.; Bartuce, A.; Mobley, J. K.; Free, H. C.; Smith, B. G.; Harris, P. J.; Ralph, J. Highly decorated lignins in leaf tissues of the Canary Island date palm. Plant Physiol. 2017, 175, 1058-1067.

(45) Martínez, A. T.; Rencoret, J.; Marques, G.; Gutiérrez, A.; Ibarra, D.; Jiménez-Barbero, J.; del Río, J. C. Monolignol acylation and lignin structure in some nonwoody plants: A 2D NMR study. Phytochemistry 2008, 69, 2831-2843.

(46) Roupe, K. A.; Remsberg, C. M.; Yáñez, J. A.; Davies, N. M. Pharmacometrics of stilbenes: seguing towards the clinic. Curr. Clin. Pharmacol. 2006, 1, 81-101.

(47) Piotrowska, H.; Kucinska, M.; Murias, M. Biological activity of piceatannol: leaving the shadow of resveratrol. Mutat. Res., Rev. Mutat. Res. 2012, 750, 60-82.

(48) Tolbert, A.; Akinosho, H.; Khunsupat, R.; Naskar, A. K.; Ragauskas, A. J. Characterization and analysis of the molecular weight of lignin for biorefining studies. Biofuels, Bioprod. Biorefin. 2014, 8, $836-856$ 